\title{
Tradições Intelectuais na Ciência Política Brasileira Contemporânea
}

\section{Fernando Leite}

Universidade Federal do Paraná (UFPR), Curitiba, PR, Brasil. E-mail: ferngutz@gmail.com

\section{INTRODUÇÃO}

\begin{abstract}
Ciência Política brasileira contemporânea é uma disciplina di$A$ versa e recentemente tem atingido um expressivo grau de autonomia. Por um lado, multiplicam-se programas de pós-graduação específicos, destacados das demais Ciências Sociais. Desde 2000, o número de programas de mestrado e de doutorado mais que triplicou. Somente nos últimos seis anos foram fundados 21 programas - mais do que em todo o período de 1967 a 2006 (Marenco, 2015:13-14). Por outro, tem-se uma produção complexa e cada vez mais extensa, na qual, além da criação de periódicos especializados, proliferam-se e legitimam-se novas áreas temáticas e coexistem abordagens teórico-metodológicas por vezes diametralmente opostas. Os tempos em que os estudos políticos eram propriedade de alguns poucos pensadores em um regime de produção fundamentalmente escolástico, individual e polivalente vão dando lugar a uma disciplina cada vez mais profissionalizada, baseada em núcleos de pesquisa, marcada pela especialização do conhecimento, mais sensível a demandas técnicas etc.
\end{abstract}

O crescimento institucional e intelectual de uma disciplina está ligado a um processo de institucionalização e profissionalização. Assim sendo, faz todo o sentido que uma disciplina atualmente tão preocupada com

DADOS - Revista de Ciências Sociais, Rio de Janeiro, vol. 60, n3, 2017, pp. 751 a 791. 
instituições esteja também preocupada com sua própria institucionalização. A preocupação é legítima: assim como no campo político, a história e o arranjo das instituições de um campo acadêmico condicionam a prática que ali se desenrola e, assim, seu futuro.

Fundamentalmente, instituições têm um sentido cognitivo, normativo ou regulativo. No cognitivo trata-se de fornecer um quadro de percepção, definindo-se, pelo condicionamento, de que maneira as informações são interpretadas. No normativo, trata-se de indicar qual é o comportamento apropriado em uma dada situação, focando-se o papel da inculcação de crenças e valores nos agentes e, por meio deste prisma, analisando-se a eficácia e o funcionamento das normas. No regulativo, instituições são regras e seu propósito, semelhante ao normativo, é regular o comportamento dentro de seus confinamentos - sem, contudo, focar na inculcação de valores e geralmente referindo-se a constrangimentos explícitos à não conformidade. Organizações, por sua vez, podem ser entendidas como arranjos artificiais de regras e posições estatutárias que definem procedimentos previamente fixados, distinguidas por fronteiras delimitadas (aspecto formal e nominal) e, normalmente, dotadas de valoração específica dessas regras e posições, um esprit de corps (aspecto informal).

O estabelecimento de uma disciplina depende do estabelecimento de um arranjo extenso de instituições e organizações em todas essas dimensões, entre os quais uma nova profissão que, nas Ciências Sociais brasileiras, acabou andando lado a lado com autonomia acadêmica ou mesmo como condição de cientificidade. Fatores endógenos, como tradições e formação acadêmica, e exógenos, como o contexto político e as fontes de financiamento, costumam ser considerados na explicação da formação da disciplina.

A literatura sobre a Ciência Política brasileira costuma focar alguns desses fatores e concentra-se em São Paulo, Rio de Janeiro e Minas Gerais. Privilegiando fatores endógenos, Quirino (1994), Almeida (2001) e Peixoto (2001) descreveram a institucionalização do Departamento da Ciência Política na Universidade de São Paulo (USP), sua simbiose originária com as cátedras de Sociologia e a influência da tradição francesa sobre o modelo de atividade intelectual adotado e as abordagens teórico-metodológicas empregadas - contrastando com a influência da tradição estadunidense nos casos da Antropologia e da Ciência Política delineados em Peixoto (2001). Leite e Codato (2013) mostram a importância do Sistema Qualis ${ }^{1}$ na autonomização institucional e 
teórico-metodológica da Ciência Política, e Marenco (2015) mede sua institucionalização e analisa os efeitos dos mecanismos de avaliação do Qualis sobre a situação institucional e a qualidade da produção da Ciência Política brasileira. Werneck Vianna et al. (1998) fizeram uma geografia da produção universitária em Ciências Sociais, nas quais se expressa a guinada institucionalista e o campo relativamente restrito da Ciência Política à época, no alvorecer do desenvolvimento institucional identificado por Marenco (2015), Trindade (2007) e outros.

Privilegiando fatores exógenos, Arruda $(1995,2001)$ considerou condições sociais, econômicas e políticas que influenciaram os cursos da Faculdade de Administração e Ciências Econômicas de Minas Gerais (FACE) e, assim, a carreira dos cientistas políticos mineiros que seriam decisivos na institucionalização da Ciência Política - e em codificar nesta uma maneira específica, mais "positivista", de estudar fenômenos políticos. Buscando explicar o posicionamento intelectual da Ciência Política, Miceli $(1990,1993)$ sugeriu a influência do contexto político (Guerra Fria, radicalização ideológica) e da situação do campo acadêmico nacional durante as décadas de 1950 e 1970 (reforma universitária, proeminência marxista) na formação da disciplina - fatores sintetizados nos estímulos da Fundação Ford, que teria contribuído para "exportar" padrões estadunidenses de trabalho acadêmico, abordagens empiricamente orientadas e métodos quantitativos.

Considerando fatores endógenos e exógenos, Lamounier (1982) deu atenção à profissionalização da Ciência Política e considerou as "condições institucionais" da atividade intelectual e a importância de uma tradição intelectual prévia de estudos políticos (o período pré-acadêmico chamado de "pensamento político brasileiro"). Por sua vez, Trindade (2007) identificou a influência de tradições na formação de centros importantes de Ciências Sociais, e em Trindade (2012) analisa a trajetória de elites universitárias responsáveis pelo estabelecimento dos principais centros de ensino e pesquisa, sobretudo do eixo Rio-São Paulo (com exceção do Instituto Universitário de Pesquisas do Rio de Janeiro - IUPERJ), considerando propriedades socioeconômicas (origem social), acadêmicas (locais de formação, posições no campo acadêmico) e contextuais (influência do contexto político, atuação de agências de fomento). Em abordagem semelhante, Forjaz (1997) analisou a institucionalização da Ciência Política focando o grupo de cientistas políticos mineiros e cariocas responsáveis pela fundação de cursos de pós-graduação na Universidade Federal de Minas Gerais (UFMG) e no IUPERJ, no final da década de 1960, sugerindo a impor- 
tância da "autonomia da política", por eles propugnado, no estabelecimento da disciplina.

Agregando as abordagens de Miceli, Forjaz e Lamounier, Keinert e Silva (2010) analisaram os fatores responsáveis pelas disposições mentais que influenciaram a abordagem de mineiros e cariocas, segundo estes mais científica, focando a reapropriação do chamado "pensamento político brasileiro" para basear a noção da "autonomia da política" e uma visão mais otimista das instituições políticas brasileiras. Entre os fatores considerados está a formação na FACE, a influência das tradições intelectuais do Rio de Janeiro e de Minas Gerais, da Ciência Política estadunidense e a concorrência com a sociologia paulista.

Mas faltam análises mais sistemáticas sobre a dimensão intelectual do campo, em particular sua produção. Reis (1997) e Soares (2005) avaliaram a qualidade da produção e defenderam mais rigor metodológico posicionando-se em um conflito entre tradições intelectuais em prol do polo científico. No entanto, o propósito desses trabalhos foi, antes, identificar e dosar insuficiências do campo do que propriamente reconstruí-lo².

Em particular, nenhum trabalho buscou efetivamente reconstruir o campo da Ciência Política. O termo é usado sem observar as exigências implicadas em seu emprego - em particular responder à questão dos princípios que organizam a produção. Análises focam áreas específicas ou, como é o caso das avaliações sobre a qualidade da produção, analisa-se $a$ disciplina a partir de uma visão disciplinar específica, tomando uma propriedade particular como critério de definição da disciplina. Além disso, o emprego incompleto do conceito de campo produz distorções importantes, como a "pluralidade" presentemente identificada no "campo" da Ciência Política (Lessa, 2010, 2011; Amorim Neto e Santos, 2015), detendo-se no instante em que, além de diferenças, ele desvelaria desigualdades. As poucas análises que visam reconstruir o sistema de oposições, como Keinert e Silva (2010), focam os condicionantes exógenos da produção sem avaliar a sua estrutura.

Sem tomá-las como o objeto da análise, a literatura sugere que oposições como humanístico e científico, empírico e teórico, nomotético e ideográfico, entre outras, atravessam as Ciências Sociais. Indícios mais claros são encontrados em Fábio Wanderley Reis (1997), que descreveria as Ciências Sociais brasileiras como "descritivas", "idiográficas", "jornalísticas", "historiográficas" e "etnográficas", destacando o fraco treinamento metodológico, diagnóstico estendido à Ciência Política, 
na qual faltaria "rigor analítico", "vocação teórica e nomológica" e "cumulatividade". Uma década depois, Gláucio Soares (2005) identificaria defeitos semelhantes, ressaltando a falta de rigor do treinamento metodológico. Segundo ele, a maior parte dos trabalhos não tinha método algum; a ausência de método era confundida com "quali", por sua vez confundido com ensaísmo; abundariam estudos de um só caso; os únicos trabalhos metodologicamente informados seriam quantitativos, que seriam escassos e raramente empregariam estatísticas mais sofisticadas. Lima Júnior (1999) também ressalta o "ensaísmo" e o enfoque demasiado teórico.

Amorim Neto e Santos (2005) e Pogrebinschi (2014) ressaltaram as persistentes oposições entre "orientações empíricas e teóricas" na disciplina e, dez anos depois, a "valorização excessiva" de métodos quantitativos e a "virtual ausência" de métodos qualitativos (Amorim Neto e Santos, 2015), ecoando o diagnóstico de Soares (2005). Nesse sentido, oposições mais profundas, envolvendo modelos de atividade intelectual, manifestam-se em Cano (2012), em que se menciona a valorização da "erudição" e o culto ao autor - propriedades típicas da figura histórica do polímata, central no modelo humanístico.

Este artigo preenche parte dessas lacunas. Faz-se uma análise do campo de produção norteando-se pelas seguintes questões: tradições intelectuais importam na estruturação da produção? Há oposições que presentemente organizam a produção?

Em primeiro lugar, a produção é reconstruída identificando-se um espaço relacional de distâncias e oposições entre categorias. A análise toma três categorias como eixos: periódicos, áreas temáticas e abordagens teórico-metodológicas. A seguir, são identificadas as dimensões e os fatores responsáveis por determiná-la, dispondo e discriminando as categorias. $\mathrm{O}$ trabalho então mostra a importância das tradições intelectuais na estruturação do campo e responde a parte das especulações sobre a predominância de tal ou qual categoria ou a persistência de tal ou qual oposição na Ciência Política brasileira ${ }^{3}$.

\section{METODOLOGIA}

\section{Recorte}

Foram analisados 567 artigos dos periódicos nacionais A1, A2 e B1 listados no Qualis da área de Ciência Política ${ }^{4}$. Foi considerada a classifi- 
cação mais recente disponível no instante da coleta de dados, publicada em 2013. O período de análise cobriu o triênio correspondente à última avaliação da pós-graduação pela CAPES (2010-2012).

Tendo em vista que a produção da maior parte dos periódicos é interdisciplinar, a escolha dos artigos seguiu os seguintes critérios: (i) vínculo institucional: ser vinculado a um programa de pós-graduação da área de Ciência Política, segundo a CAPES; (ii) identificação subjetiva: incluir a Ciência Política como área de atuação no currículo Lattes; (iii) participação no Encontro da Associação Brasileira de Ciência Política (ABCP); e (iv) participação em banca de doutorado em Ciência Política.

A referência é o primeiro autor dos artigos. Não foram consideradas revisões de literatura, introduções, apresentações, resenhas, opiniões, entrevistas, homenagens, críticas e semelhantes. Os critérios evitam lançar mão de uma definição arbitrária ou "ontológica" de Ciência Política, além de contemplar zonas fronteiriças da disciplina - isto é, interseções e frentes de heteronomia com outras disciplinas, em particular a Sociologia. Sendo os artigos a unidade de observação, os periódicos são tratados como propriedades da produção, assim como áreas temáticas, abordagens e tradições intelectuais ${ }^{5}$.

\section{Categorias de Análise}

A categoria mais institucionalizada das três, os periódicos, é o principal eixo de organização da produção. Periódicos operam como árbitros filtrando as propriedades da produção consideradas legítimas na região na qual o periódico se insere. A hierarquia dos periódicos, assim, expressa a hierarquia das regiões. Também condicionam a produção dos programas de pós-graduação, que precisam inculcar temas e abordagens reconhecidos, com mais chances de publicação nos periódicos mais valorizados. Atuando dessa forma, os periódicos contribuem para definir a identidade da disciplina.

Áreas temáticas são conjuntos mais ou menos institucionalizados de objetos de pesquisa afins. É a segunda categoria mais institucionalizada da produção. Áreas têm uma função alocativa. Elas delimitam a margem de objetos passíveis de serem estudados, delimitando fronteiras. Seguindo uma abordagem pragmática (Kuhn, 1962; Kaplan, 1964:42-43), elaborou-se uma lista de áreas temáticas em função das "Áreas do Conhecimento" da CAPES/Conselho Nacional de Desen- 
volvimento Científico e Tecnológico $(\mathrm{CNPq})^{6}$ e das "Áreas Temáticas" (ATs) da $\mathrm{ABCP}^{7}$, ajustadas ao conteúdo dos trabalhos analisados ${ }^{8}$.

Uma abordagem teórico-metodológica é uma composição de fatos cognitivos (ideias) e ocorrências linguísticas (palavras, termos, expressões). Esses elementos são diretamente expressados em textos (artigos, papers, livros etc.), podendo, assim, ser indiretamente observados ao nos referirmos à sua expressão escrita, tomada como um dado da experiência.

Substantivamente, uma abordagem refere-se (i) a um conjunto de ideias a respeito de um objeto, (ii) a procedimentos mobilizados para estudá-lo e (iii) a atributos, fatores ou variáveis que o analista supõe, deduz ou infere ao estudar o objeto.

As abordagens são frequentemente trazidas à consciência e classificadas, muitas vezes em ismos, identificando posições na estrutura intelectual do campo, isto é, abordagens nominais: "neoinstitucionalismo", "marxismo", "pluralismo" etc. A listagem das abordagens nominais foi feita com base em manuais, trabalhos sobre a história da disciplina e referências substantivas 9 .

Uma tradição é um conjunto mais ou menos coeso de ideias e hábitos de pensamento historicamente persistentes, um conjunto de disposições mentais que fornece parâmetros gerais de interpretação do real. Nesta pesquisa investigamos tradições relativas ao escopo, âmbito, natureza do objeto e modelos de atividade intelectual.

Escopo e amplitude do argumento referem-se a oposições clássicas das Ciências Sociais que se verificou também se aplicarem à Ciência Política. O escopo avalia a qual extremo o argumento está mais próximo, dentro da oposição nomotético-idiográfico. Quanto mais nomotético, mais as inferências realizadas inclinam-se à generalização; quanto mais idiográfico, mais o raciocínio inclina-se ao delineamento de especificidades. A amplitude verifica a qual extremo está mais próxima a articulação entre objeto e fatores, dentro da oposição clássica agência/subjetivismo e estrutura/objetivismo. Quanto maior o caráter coletivo, quanto mais amplos e sistêmicos os termos utilizados para descrever o objeto, mais estrutural ele é; inversamente, quanto mais dependentes da ação, individual ou de um grupo ou organização, mais próximo da agência ${ }^{10}$. 
A natureza do objeto pode ser empírica, teórica ou linguístico-ideal. No primeiro caso, o objeto de estudo refere-se a um observável direto, indireto ou a um constructo (como os termos "Estado" e "cultura"). Um objeto teórico é um termo abstrato, componente de um sistema teórico. Um objeto linguístico-ideal é uma construção linguística ou um fato mental, como uma ideia, um texto ou um pensamento, sem constituir um termo teórico. Modelos de atividade intelectual, científico e humanístico, também se opõem na Ciência Política brasileira. Historicamente, o modelo humanístico funda-se na estrutura curricular do studia humanitatis que reformou as universidades europeias entre os séculos XV e XVI e suas ramificações. Com a autonomização das "ciências empíricas", entre os séculos XVII e XVIII, o modelo humanístico incorpora a Filosofia até chegar ao atual modelo "Filosofia, Letras e Artes" (Burke, 2000:18-22, 81-115).

O modelo científico tem como principal faculdade a explicação e o que é como questão central. Distingue-se do modelo humanístico ao interessar-se fundamentalmente pela prova de proposições específicas. Historicamente, vincula-se à autonomização da "Filosofia Natural" a partir do século XVIII e da ascensão do empirismo epistêmico, que lança as bases epistemológicas das ciências naturais. É nesse contexto que decorre a distinção entre "conhecimento qualitativo" e "conhecimento quantitativo", a partir do qual o modelo científico, centrado na Física, adota a matemática (ibidem:85-86).

Para distinguir e medir as tradições científica e humanística, partimos da tipologia dos "estilos cognitivos", proposta por Kaplan (1964:259-262), adaptada ao contexto da Ciência Política. Um estilo cognitivo é a forma de perceber, interpretar e apresentar informação, uma forma de compreensão. Selecionamos os seguintes estilos: "literário", "acadêmico", "erístico" e "simbólico". Os estilos cognitivos propostos por Kaplan, entretanto, supõem um campo acadêmico autônomo, não considerando influência, por exemplo, de imperativos políticos, como é praxe nas ciências humanas. Assim, adicionamos o estilo militante. A referência é a figura do "intelectual militante" (Said, 2005; cf. Martins, 1987).

O estilo literário tem como principais faculdades a compreensão e a interpretação e tem como questão fundamental qual é o sentido. Envolve as seguintes características: (i) tende a ocupar-se de indivíduos, pessoas particulares ou conjuntos de eventos, estudos de caso, descober- 
tas clínicas etc.; (ii) uma sequência comportamental ou uma articulação de eventos são reveladas de modo a ter certa significância; (iii) uma pessoa, um movimento ou uma cultura são interpretados, geralmente nos propósitos e perspectivas específicas dos atores, em vez de categorias abstratas e gerais do esquema explanatório do analista.

O estilo acadêmico envolve fundamentalmente a ideação, a conjetura e a especulação. Tem as seguintes características: (i) é mais abstrato e geral do que o estilo literário; (ii) há mais precisão na especificação do sentido dos termos; (iii) termos adquirem um caráter sistemático, isto é, ele é eminentemente conceitual. O que chamamos hoje de "ensaio" geralmente emprega o que Kaplan chama de estilo acadêmico, como fica claro na distinção de Waizbort (2006:37-38). Historicamente, ele está na interseção da filosofia com a literatura, tomando forma à medida que os humanistas foram sendo incorporados às universidades.

O estilo erístico tem como principal faculdade a explicação e $o$ que é como questão central. Distingue-se do literário e do acadêmico ao interessar-se fundamentalmente pela prova de proposições específicas. Nesse sentido, apresenta as seguintes características: (i) dados tornam-se importantes; (ii) distinguem-se mais claramente proposições de conteúdo empírico; (iii) dá-se atenção a "relações dedutivas" e "derivações lógicas de proposições previamente estabelecidas ou explicitamente assumidas"; (iv) definições são frequentes; e (v) exibe-se mais "consciência do que se pensa ser os cânones do 'método científico'" (idem:259-260; ênfases minhas).

O estilo simbólico apresenta maior grau de formalização e a matemática cumpre um papel fundamental. Nesse sentido, (i) o objeto é conceitualizado em função de termos matemáticos; (ii) notações específicas são introduzidas; (iii) os símbolos são submetidos a "transformações matematicamente padronizadas"; (iv) a mensuração é importante e provê conteúdo às formas matemáticas (idem:260). Dito isso, não se trata de um estilo formal ou postulacional puro - o conteúdo empírico é fundamental, não se focando nas demonstrações matemáticas. A matemática não é a finalidade, mas o meio de abordar objetos empíricos.

O estilo militante funda-se nas faculdades de criticar, propor, arquitetar; em dirigir o que é ou transformar no que deve ser. É, antes de tudo, um argumento em favor da transformação ou conservação de um estado de coisas. Possui as seguintes características: (i) orienta-se para a proposta de planos de ação; (ii) envolve a articulação de forças ou recursos 
para dispor e constituir as coisas do modo que se considera mais adequado; (iii) realiza ou apropria-se de considerações de fato (como os produtos dos estilos analíticos) para propor o plano de ação.

Por exemplo. Queremos saber o que pensam os corredores de maratona. É um objeto interessante porque é um esporte que estimula a ideação, enevoando a distinção clássica entre "ação" e "reflexão". Assim, Samson et al. (2015) colocaram microfones em corredores e pediram para que narrassem o que pensavam durante a corrida. As narrativas foram então classificadas e a experiência reduzida a certas categorias comuns, no melhor estilo erístico. Gardner (2014), por outro lado, registrou sua experiência de corridas matinais em um diário, descrevendo sensações e refletindo sobre questões que o afetavam durante a prática, no melhor estilo literário. Um ensaísta, por sua vez, poderia partir de Gardner e meditar sobre imbricação entre solidão e reflexão, enquanto outro autor poderia inspirar-se no mesmo ensaísta e defender a inclusão de corridas na grade de educação física.

Os estilos cognitivos foram então agregados: o modelo humanístico compõe-se pelos estilos literário, acadêmico e militante; o científico, pelos estilos erístico e simbólico. Essa solução nos aproxima da distinção de Snow (1959) entre culturas "literária" e "científica".

O estilo acadêmico foi incluído em "humanístico" em virtude da aproximação entre a Filosofia e as disciplinas humanísticas (Burke, 2000). Herdeira desse modelo humanístico, uma cultura intelectual filosóficoliterária permeava a sociologia francesa (Lepenies, 1996) quando esta influencia as Ciências Sociais brasileiras no instante de sua institucionalização, durante a década de 1950, favorecendo o ensaio, cujo formato adotado aqui, em consonância com o praticado na França e na Alemanha, pode ser considerado um estilo cognitivo (Waizbort, 2006:35-37).

\section{Técnicas e Procedimento de Análise}

Em geral, lemos o resumo, as palavras-chave, a introdução e a conclusão. Em primeiro lugar, lemos o resumo e as palavras-chave atrás de categorias mais institucionalizadas, como áreas temáticas e abordagens mais difundidas (como neoinstitucionalismo). Em segundo, a introdução e a conclusão foram lidas em busca de: (i) áreas e abordagens não identificadas no resumo e nas palavras-chave; (ii) natureza do objeto de estudo, estilos cognitivos, escopo e âmbito do argumento. 
Abordagens nominais foram classificadas norteando-se pela bibliografia de referência (cf. Leite, 2015:156) e pelas palavras-chave (como "instituições políticas" e neoinstitucionalismo, "ideologia" e marxismo, "recrutamento" e análise de elites). Em geral, a codificação de cada artigo levou entre 5 e 20 minutos.

Para definir o escopo focamos as conclusões. Para nomotética, procuramos por generalizações nas conclusões; à ausência destas, procuramos pelo delineamento de especificidades no desenvolvimento (idiográfica). Para o âmbito focamos o corpo do texto, observando-se o grau de amplitude do objeto de análise e dos fatores mobilizados para abordá-lo. Além disso, também recorremos ao corpo do texto em busca da natureza das evidências (quanti, quali, híbridas ou bibliográficas).

Usamos medidas de associação como $\mathrm{V}$ de Cramer para identificar a existência de associações, análise de resíduos para identificar a força das associações e análise de correspondência para reconstruir o campo. Empregamos a técnica de análise de correspondência múltipla (HOMALS) baseada na solução de Greenacre (1984). A análise de campo toma como referência os estudos de Bourdieu (1984; 1996).

\section{NATUREZA DO OBJETO}

A presente seção responde à seguinte questão: há uma oposição entre trabalhos empíricos e teóricos na produção? Ela importa na estruturação do campo de produção? Em primeiro lugar, verificamos a distribuição de frequências e as associações entre natureza do objeto nos periódicos, áreas temáticas e abordagens. Os valores dos resíduos são fornecidos junto dos percentuais ${ }^{11}$. As medidas de associação, quiquadrado e V de Cramer são fornecidas na parte inferior das tabelas.

\section{Periódicos}

Em primeiro lugar, a produção da Ciência Política brasileira é predominantemente empírica. Não há periódico especializado em teoria: alguns periódicos são receptivos a objetos teóricos e a objetos linguísticoideais, mas não especializados neles. Apesar disso, os resíduos padronizados indicam que objetos teóricos e linguístico-ideais tendem a se concentrar em certos periódicos, mas não em outros.

Atraindo objetos teóricos tem-se Lua Nova (LN), Revista Brasileira de Ciência Política (RBCP) e Revista de Sociologia e Política. Repelindo-os 
Fernando Leite

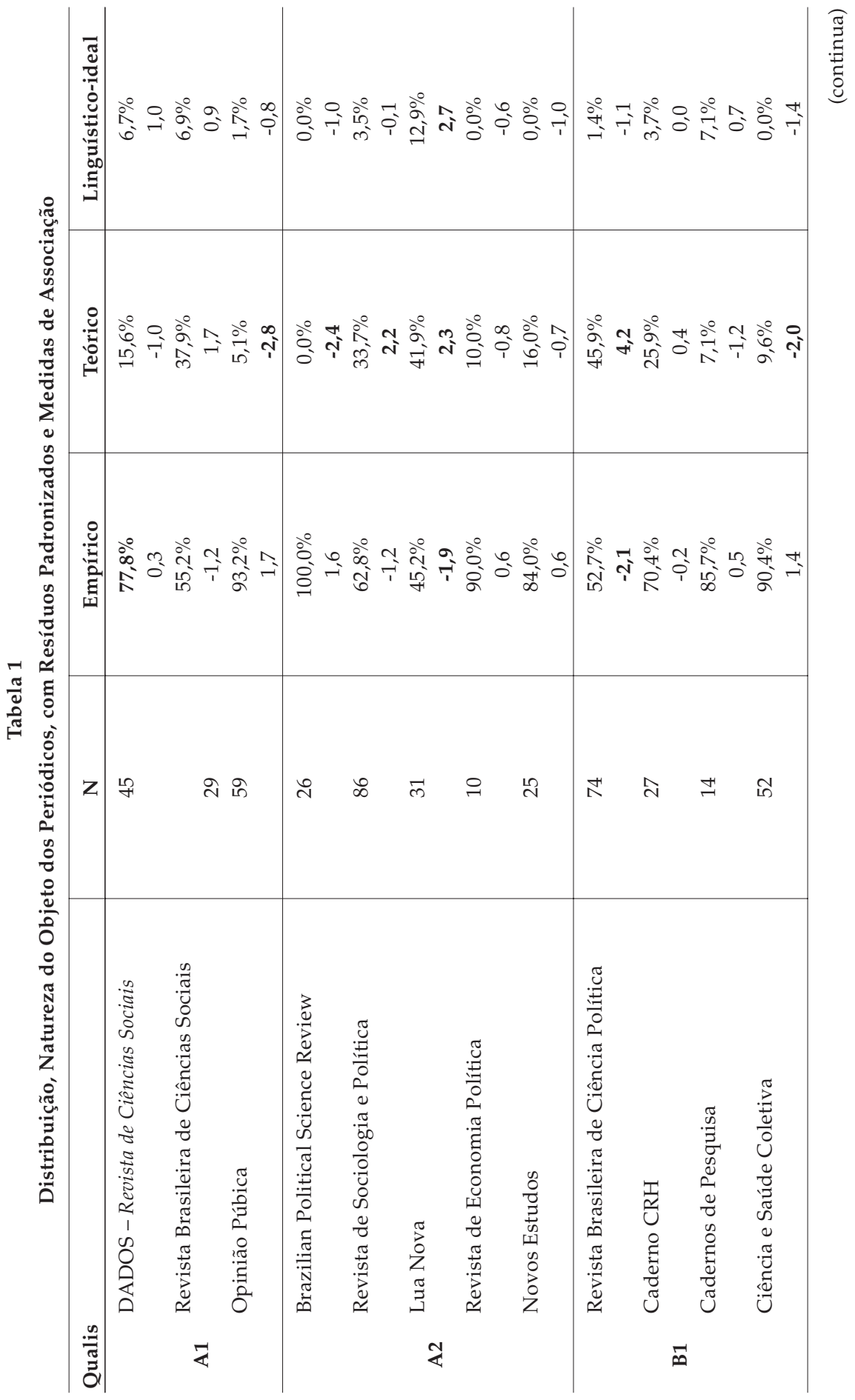

762 DADOS - Revista de Ciências Sociais, Rio de Janeiro, vol. 60, nº 3, 2017 
Tradições Intelectuais na Ciência Política Brasileira Contemporânea

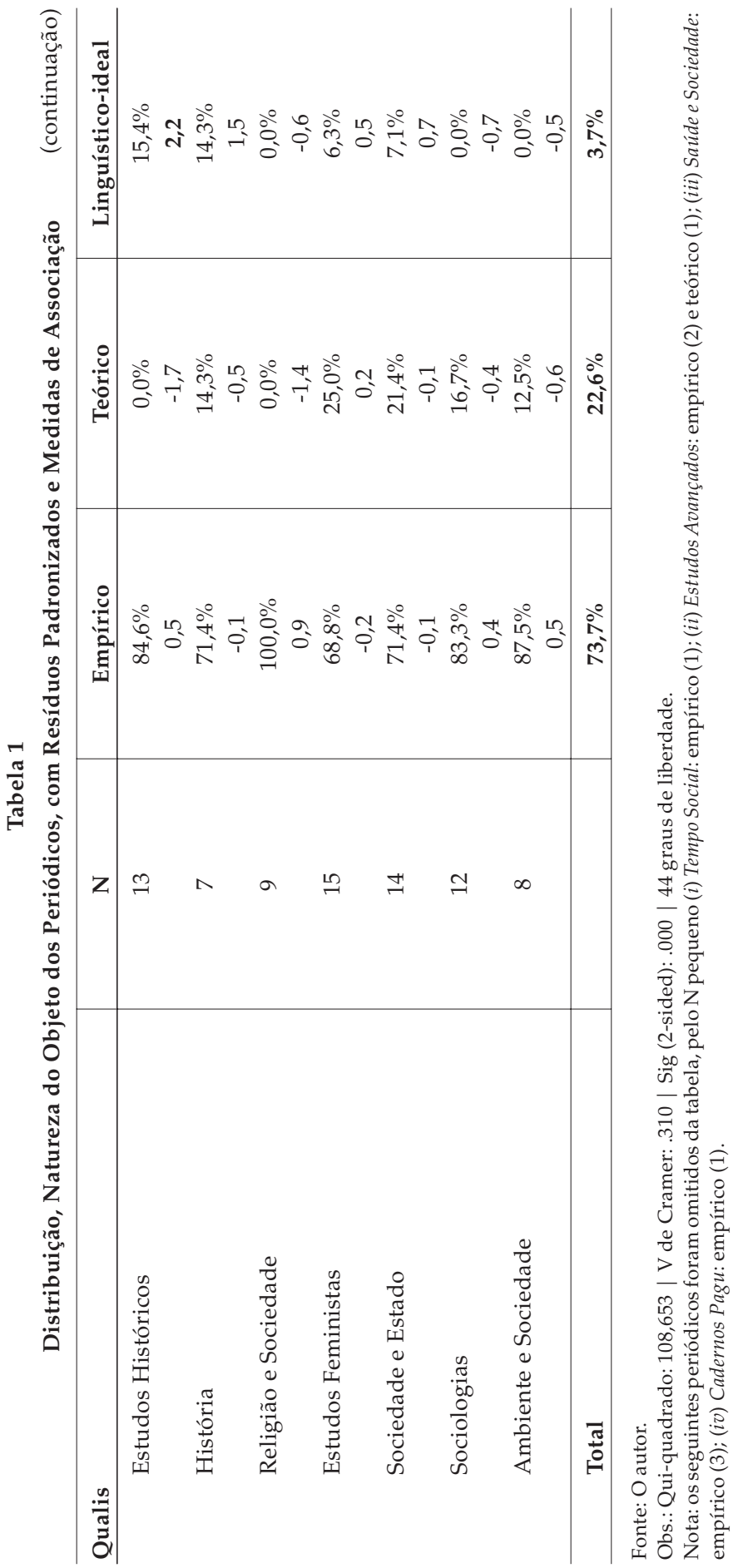

DADOS - Revista de Ciências Sociais, Rio de Janeiro, vol. 60, nº 3, 2017763 
tem-se Opinião Pública (OP), Brazilian Political Science Review (BPSR) e Ciência e Saúde Coletiva. A predominância de objetos empíricos na BPSR $(100 \%)$ e em OP $(93,2 \%)$ salta aos olhos, ao mesmo tempo por sua importância e por serem estritamente identificados com a Ciência Política.

Os resíduos indicam que a RBCP e LN repelem objetos empíricos, embora estes predominem. Isso quer dizer que, dada a predominância de objetos empíricos na produção, se esperaria que houvesse menos estudos teóricos nesses periódicos. Em outras palavras, a orientação teórica e linguístico-ideal desses periódicos é relativamente alta. São redutos de teoria no campo. Estudos Históricos também se destaca como reduto linguístico-ideal.

\section{Áreas Temáticas}

A análise reconstrói o campo a partir das instituições mais objetivadas (periódicos), procedendo para as mais práticas, "imanentes" (abordagens). Áreas são um caso intermediário: ao contrário dos periódicos, são um constructo, porém mais institucionalizado do que abordagens. A distribuição de objetos nas áreas é apresentada na Tabela 2.

A distribuição revela a orientação empírica das áreas mais identificadas com a Ciência Política: comportamento político e instituições políticas. O trabalho teórico concentra-se em áreas específicas, dedicadas à teoria.

Repare-se que as áreas societais são mais heterogêneas. A margem de teoria aumenta quando nos afastamos da política institucional. Isso sugere o afastamento das áreas mais "positivistas", institucionalistas e atitudinais em relação ao modelo humanístico de trabalho intelectual. A distribuição sugere algo similar ao manifesto na contenda entre a "filosofia política" e o mainstream da Ciência Política estadunidense (Jensen, 1969; Bellamy, 1993; Grant, 2005).

Essa contenda tem reverberação estatística: os resíduos e as medidas de associação mostram forte oposição entre áreas segundo a natureza do objeto.

É preciso insistir, entretanto, que os resultados não sugerem que as pesquisas empíricas não são informadas teoricamente ou que não almejam generalizações teóricas. Na verdade, a orientação nomotética de $41 \%$ da produção e a associação entre áreas empíricas e orientação 
Tradições Intelectuais na Ciência Política Brasileira Contemporânea

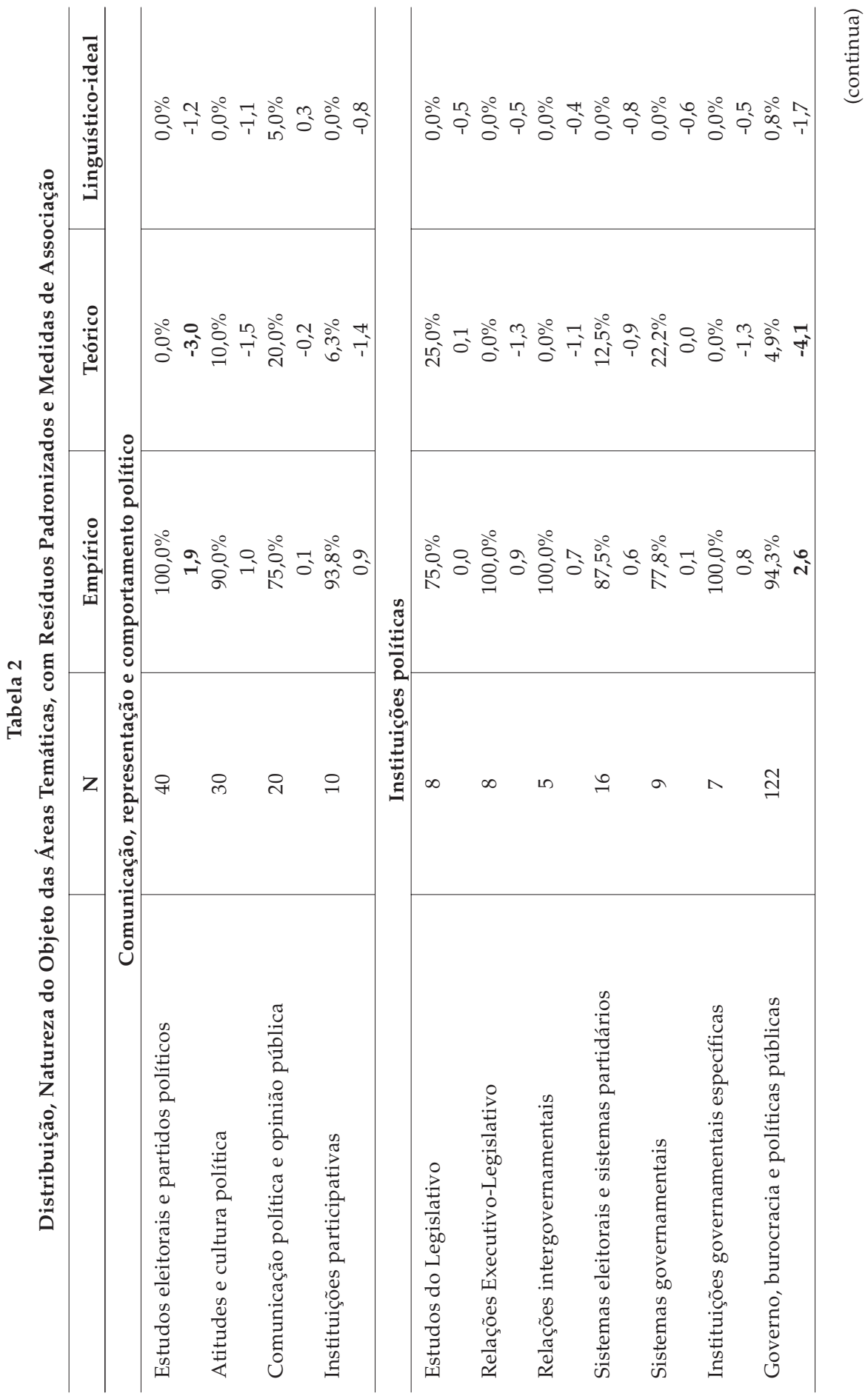

DADOS - Revista de Ciências Sociais, Rio de Janeiro, vol. 60, nº 3, 2017765 
Fernando Leite

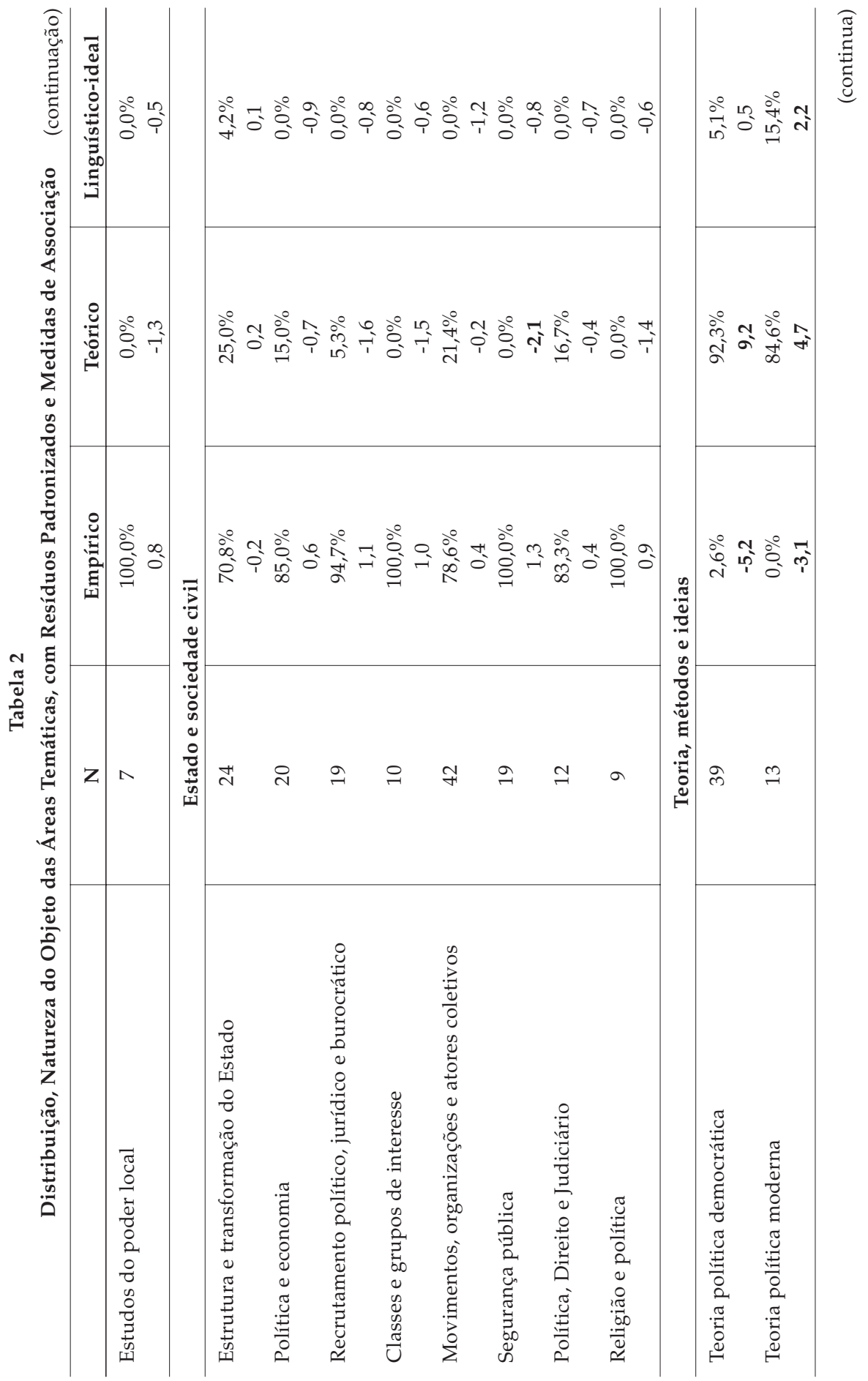

766 DADOS - Revista de Ciências Sociais, Rio de Janeiro, vol. 60, nº 3, 2017 
Tradições Intelectuais na Ciência Política Brasileira Contemporânea

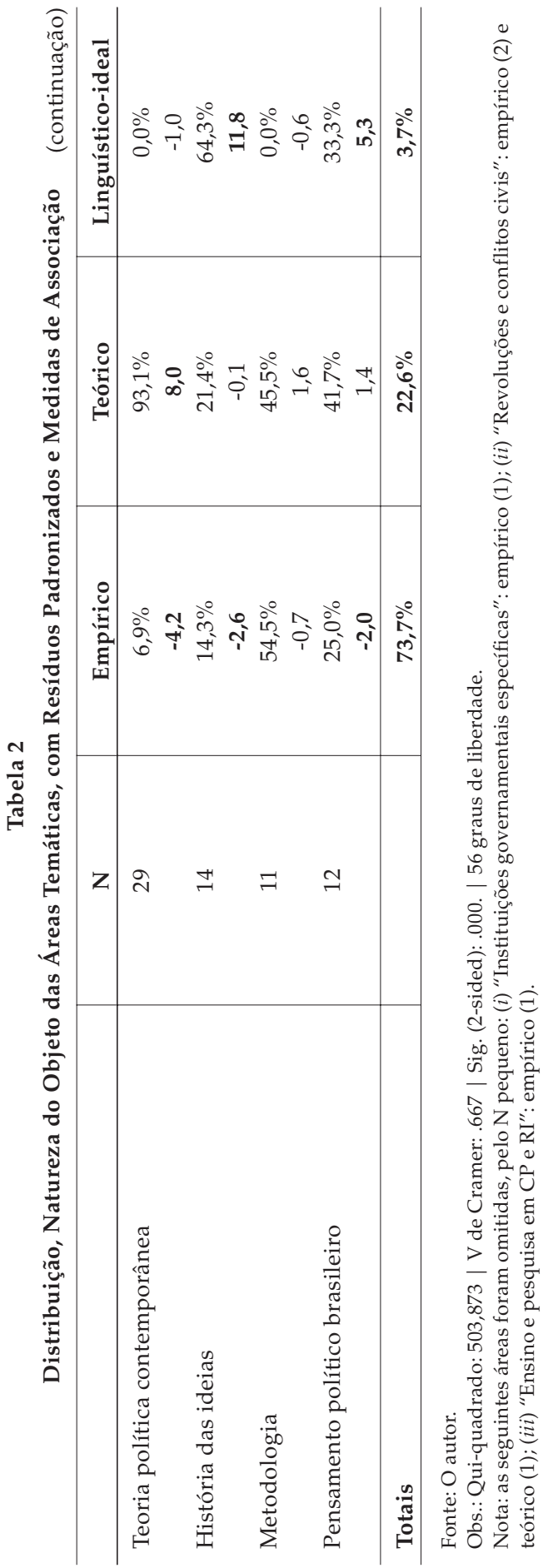

DADOS - Revista de Ciências Sociais, Rio de Janeiro, vol. 60, nº 3, 2017767 
nomotética (Leite, 2015:232) sugere vínculo entre trabalho empírico e generalização teórica. A orientação empírica, portanto, está longe da perspectiva de que os "dados falam por si mesmos".

\section{Abordagens Nominais}

Mais do que áreas, abordagens se associam com objetos de natureza empírica, teórica ou linguístico-ideal, como mostra a Tabela 3. As abordagens com valores mais expressivos (alto percentual e $\mathrm{N}>9$ ) foram ressaltadas em negrito.

As abordagens classificadas sob Ciência Política são claramente divididas entre abordagens empíricas e teóricas. As abordagens mais tradicionais - neoinstitucionalismo, cultura política, comportamentalismo, pluralismo, escolha racional e estudos de geografia eleitoral (empirismo politológico) ${ }^{12}$ são as mais empiricamente orientadas, explicitando, a nosso ver, uma posição epistemológica que associa cientificidade com pesquisa empírica. As abordagens classificadas sob Sociologia Política são um pouco menos empíricas e não há uma divisão tão forte como as de Ciência Política. A mais teórica das abordagens de Sociologia Política é o marxismo. Considerando-se que as abordagens tradicionais focam a política institucional e o marxismo a evita ou mesmo a nega, ao que parece temos uma oposição entre visões de Ciência Política. Isso se expressa nos termos nativos, como nas distinções "ciência política marxista" e "ciência política empírica".

\section{Correspondência Múltipla}

As associações sugerem que a estrutura da produção depende de distinções envolvendo a natureza do objeto de estudo. Para verificá-lo elaboramos um modelo de correspondência múltipla reunindo periódicos, áreas, abordagens e natureza do objeto (Gráfico 1).

Para facilitar a visualização das categorias no gráfico, os rótulos dos periódicos foram posicionados nas extremidades do gráfico, ligados às suas posições, representadas por um círculo, por uma linha. Os rótulos da natureza do objeto, "empírico" e "teórico", também estão nas extremidades, também ligados às suas posições por uma linha.

O modelo mostra um grupo, "teórico", na extremidade direita, e as categorias correspondentes a "empírico" em torno do centro e no quadrante esquerdo. O ponto que representa empírico está mais próximo 
Tradições Intelectuais na Ciência Política Brasileira Contemporânea

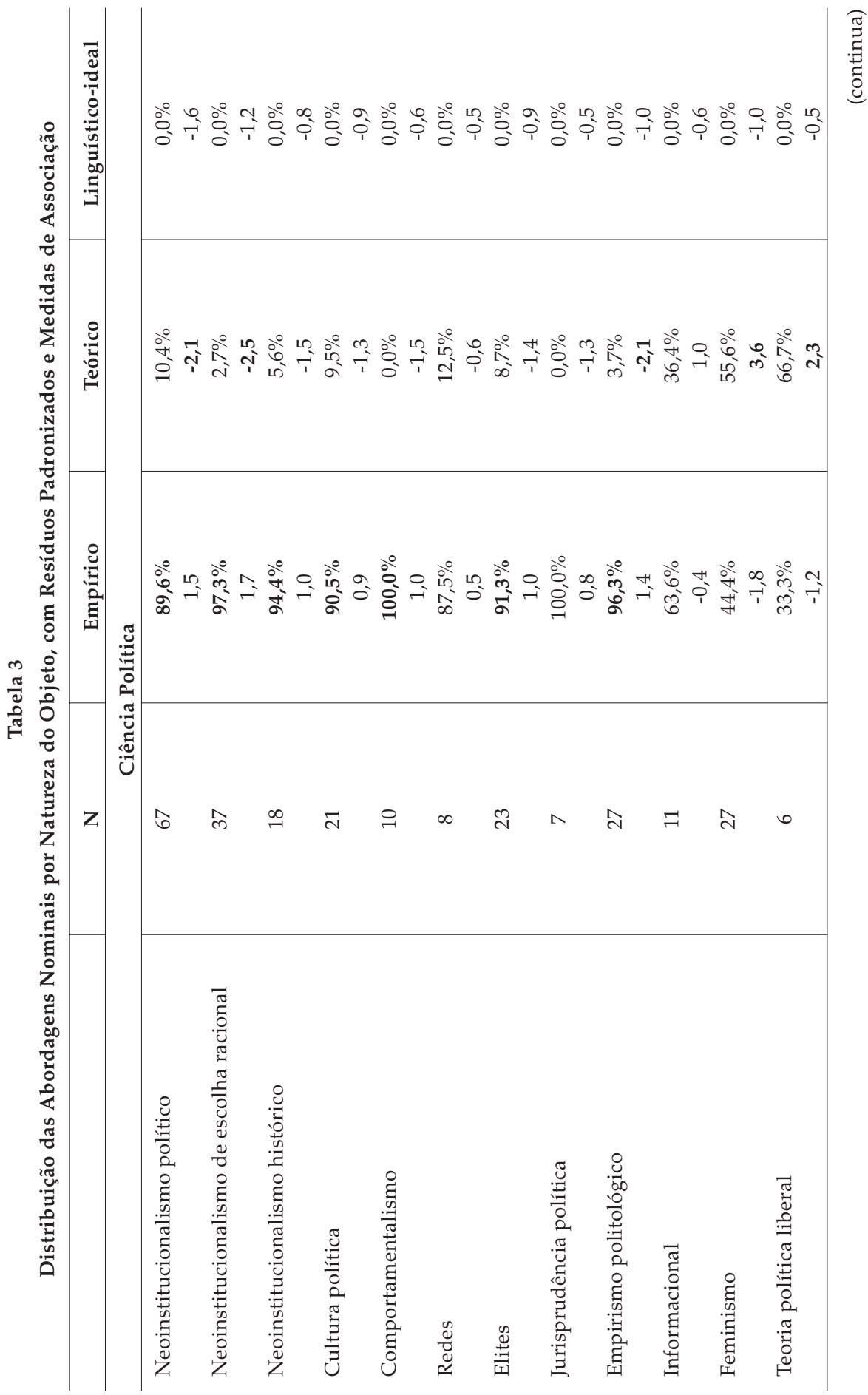

DADOS - Revista de Ciências Sociais, Rio de Janeiro, vol. 60, nº 3, 2017769 
Fernando Leite

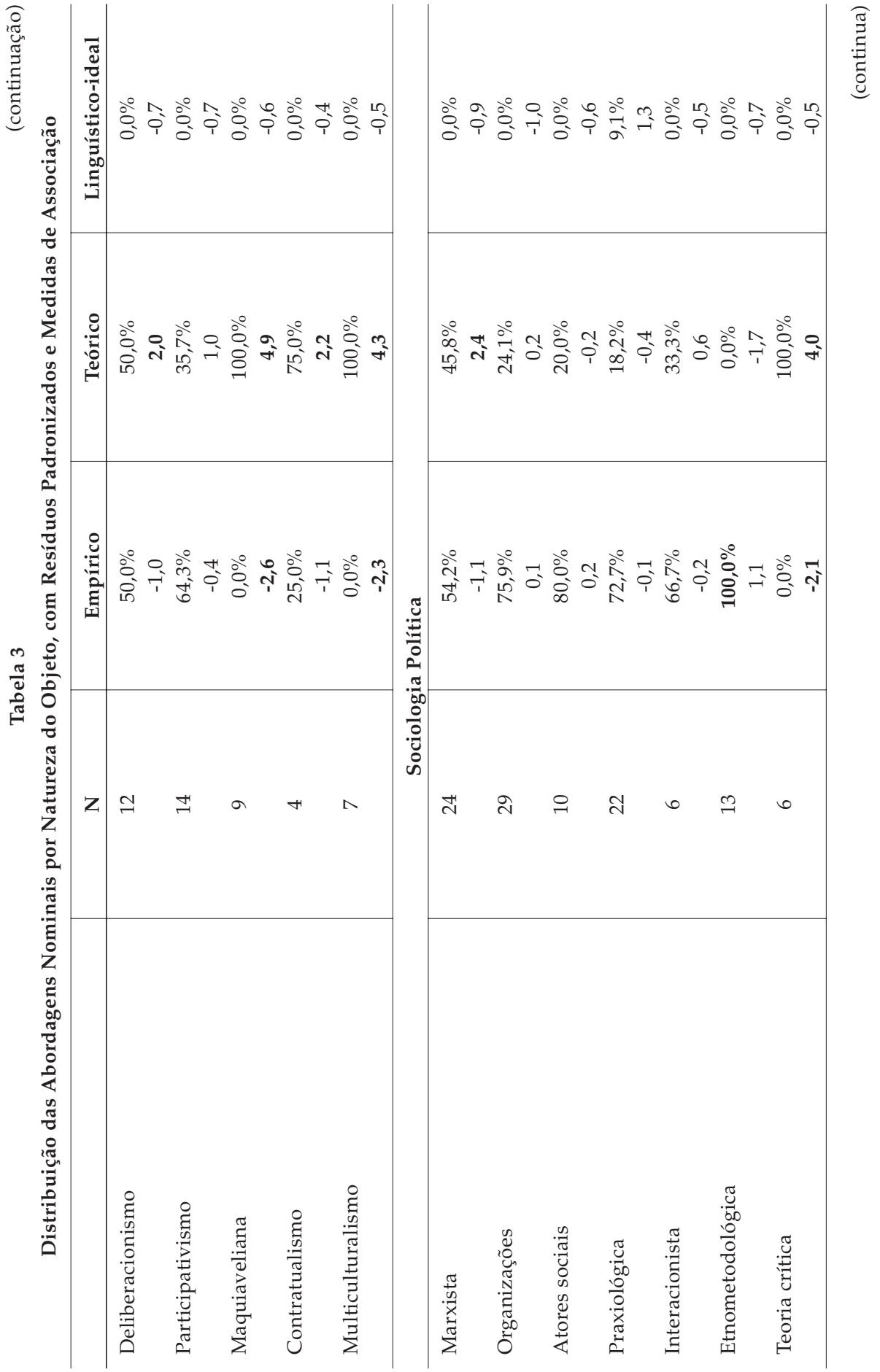

770 DADOS - Revista de Ciências Sociais, Rio de Janeiro, vol. 60, nº 3, 2017 
Tradições Intelectuais na Ciência Política Brasileira Contemporânea

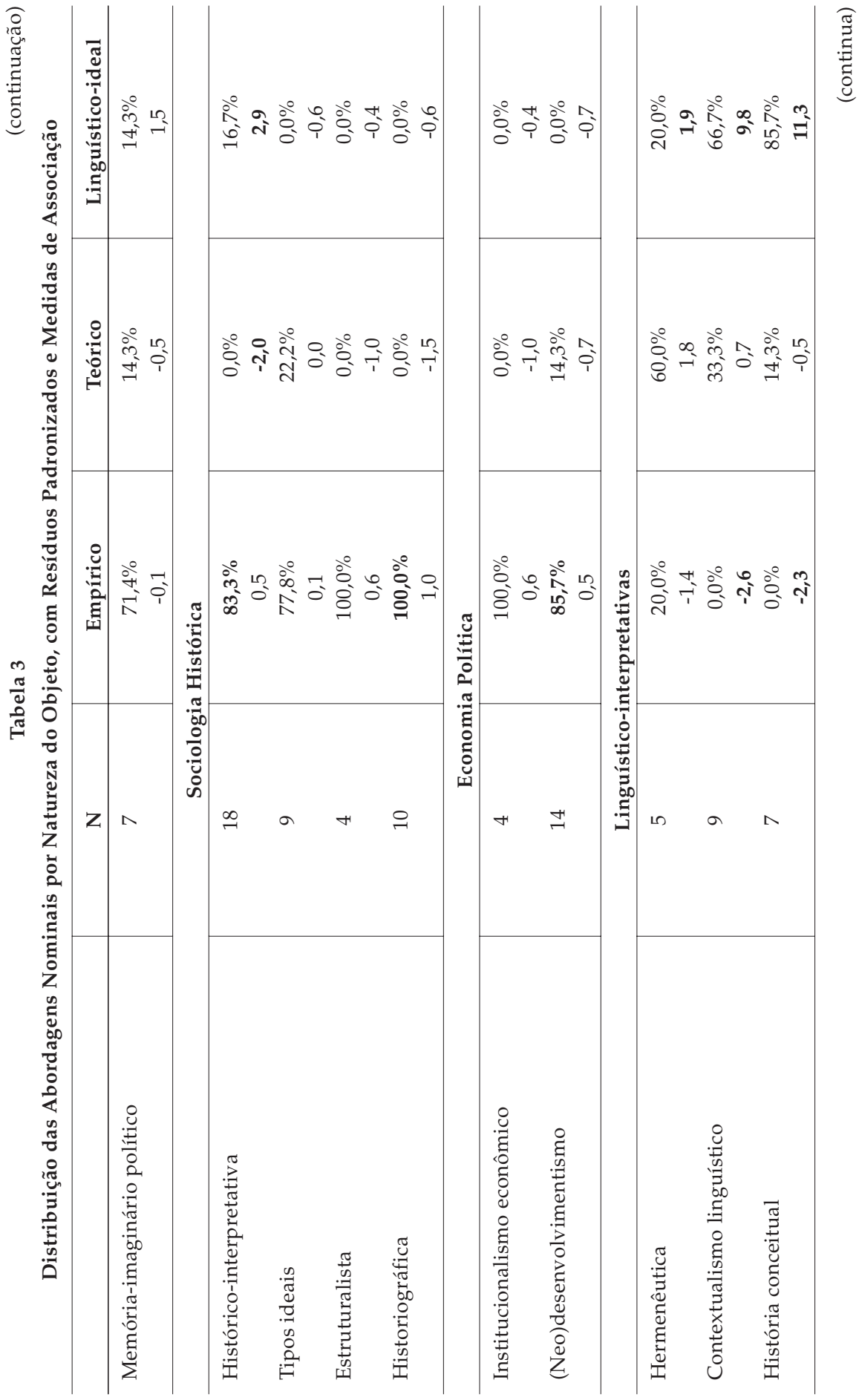

DADOS - Revista de Ciências Sociais, Rio de Janeiro, vol. 60, nº 3, 2017771 
Fernando Leite

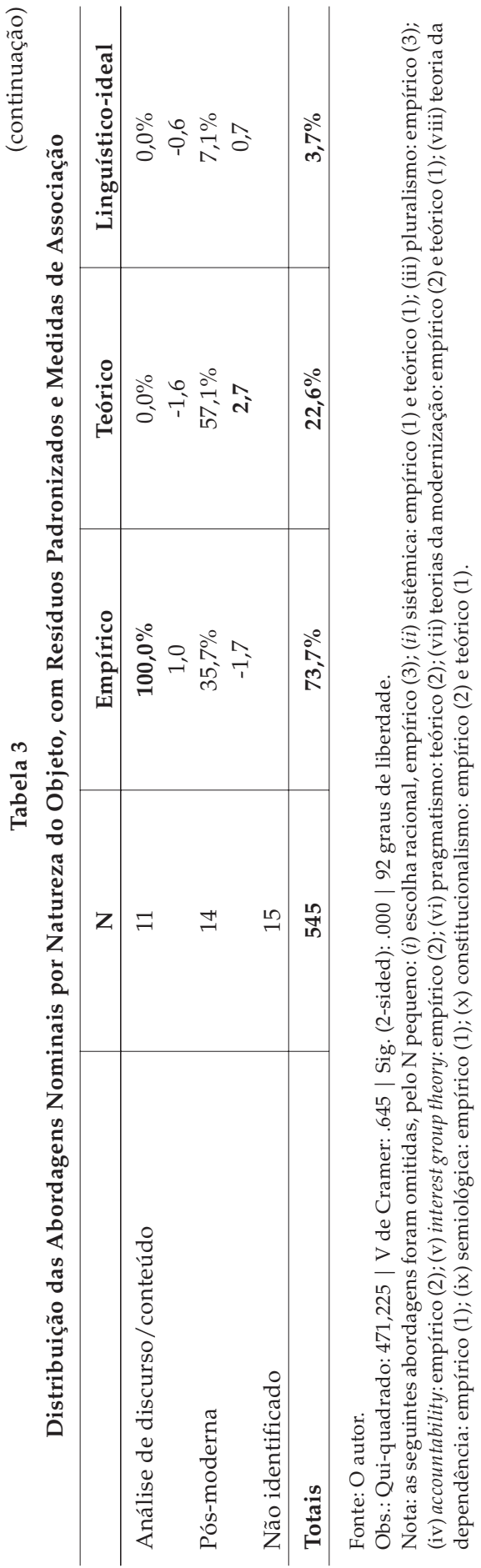

772 DADOS - Revista de Ciências Sociais, Rio de Janeiro, vol. 60, nº 3, 2017 


\section{Gráfico 1}

Correspondência Múltipla: Periódicos, Áreas, Abordagens e Natureza do Objeto ${ }^{13}$

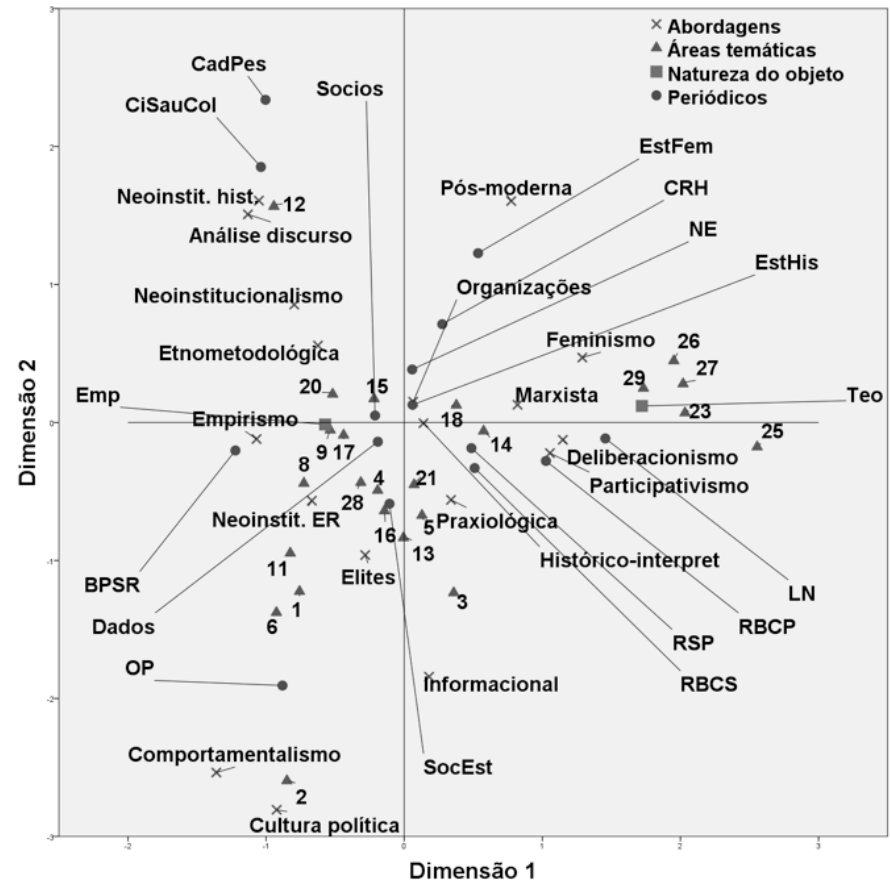

Fonte: $\mathrm{O}$ autor.

Nota: Dimensão 1: Alfa de Cronbach: .824; Variância contabilizada: 2 619; Inércia: .655. Dimensão 2: Alfa: .710; Variância: 2 139; Inércia: .535. Normalização simétrica.

ao centro, indicando o mainstream. A oposição é mais forte do lado teórico, isto é, mais forte da periferia em relação ao centro.

A oposição entre empírico e teórico parece análoga à oposição de um grupo outsider em relação ao grupo estabelecido (Elias, 2000). Ao estabelecer-se, ao transformar-se em norma, o grupo estabelecido diminui sua oposição em relação a seus adversários, enquanto mantém-se ou aumenta a oposição por parte dos grupos subalternos. A posição estabelecida produz naturalmente uma inércia (no sentido sociológico), fazendo com que as "regras do jogo" lhes favoreçam, naturalmente resistindo às investidas dos grupos subalternos. Em geral, manter a estrutura exige menos recursos do que modificá-la ou não ser excluído dela. Tudo se passa como se a dinâmica do campo funcionasse de acordo com um câmbio favorável à posição estabelecida, não sendo necessário investir tantos recursos para ocupar a posição desejada. Por outro lado, no contrafluxo, as posições periféricas têm de investir mais 


\section{Gráfico 2}

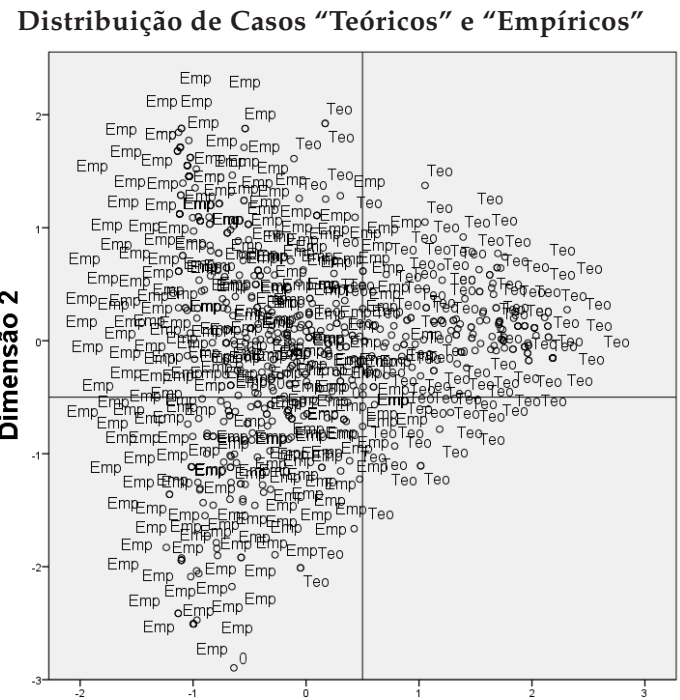

Dimensão 1

Fonte: $\mathrm{O}$ autor.

para combater uma economia que lhes é desfavorável. Isso envolve aturar os prejuízos morais associados à periferia.

Veja-se como os casos teóricos ("teo") são deslocados do centro, composto por casos empíricos ("emp"), produzindo um desvio no campo com um número relativamente reduzido de elementos: oposição por uma minoria.

Mas há uma espécie de equilíbrio desigual que pode ser atingido: o estabelecimento de uma das frações também pode implicar o insulamento da fração periférica, atenuando as oposições. Isso envolve certa aceitação de sua posição, por parte da periferia, desde que lhe seja garantida um volume mínimo de espaço e recursos. Assim, a distância estatística pode significar oposição ativa por parte do grupo periférico - ou seu insulamento. Como veremos nas medidas de discriminação, a seguir, a pontuação das áreas na primeira dimensão, largamente determinada pela natureza do objeto, é bastante expressiva, atestando a força da oposição dos objetos teóricos. A autossuficiência de microcosmos no campo geralmente exige suporte institucional - no caso, um periódico especializado, como é o caso da Economia Política (Revista de Economia Política), estudos feministas (Estudos Feministas) e de religião e política (Religião e Sociedade). Assim, a falta de um periódico teórico especializado na pro- 


\section{Gráfico 3}

Medidas de Discriminação para Natureza do Objeto, Periódicos,

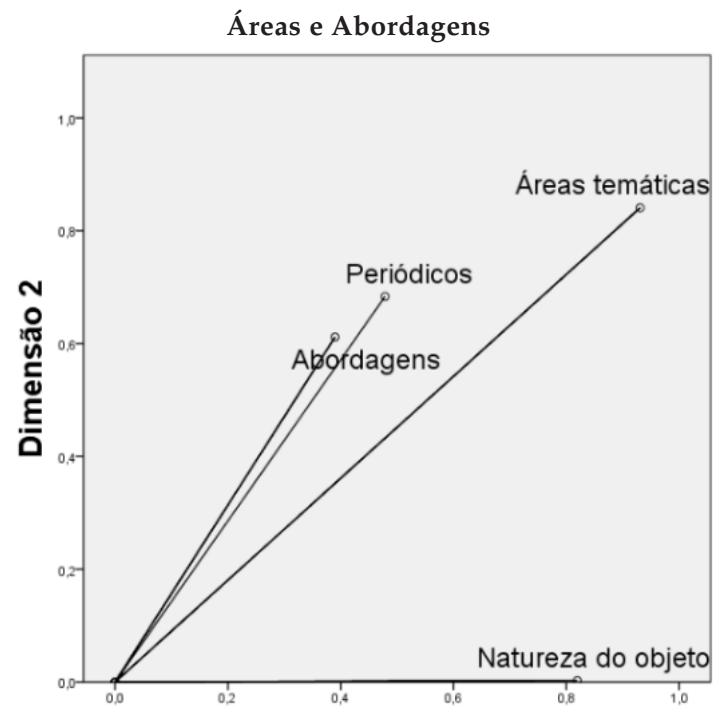

Dimensão 1

Fonte: $\mathrm{O}$ autor.

dução qualificada pode ser um agravante, fortalecendo a oposição na dimensão intelectual.

Os fatores e dimensões podem ser sintetizados conforme demonstrado no Gráfico 3.

O gráfico mostra que a oposição empírico-teórica (natureza do objeto) corresponde à primeira dimensão. O valor é superior a 0,8 , ou seja, a oposição contempla uma ampla margem de variância, indicando que a natureza do objeto é uma grande responsável pela discriminação das categorias do campo. Áreas temáticas, também com ampla margem de discriminação, contribuem para determinar ambas as dimensões. Periódicos definem e discriminam-se mais a segunda, assim como as abordagens. O gráfico também mostra que as áreas são mais especializadas que os periódicos. Nesse sentido, espera-se que os periódicos se tornem mais especializados à medida que se especializam abordagens e áreas, formalizando as distinções na dimensão intelectual.

\section{ESTILO COGNITIVO}

A presente seção responde à seguinte questão: há uma oposição entre modelos de atividade intelectual? Ela importa na estruturação do campo de produção? O modelo científico foi identificado pelos estilos 
Gráfico 4

Correspondência Múltipla: Estilos Cognitivos, Periódicos, Abordagens e Áreas ${ }^{14}$

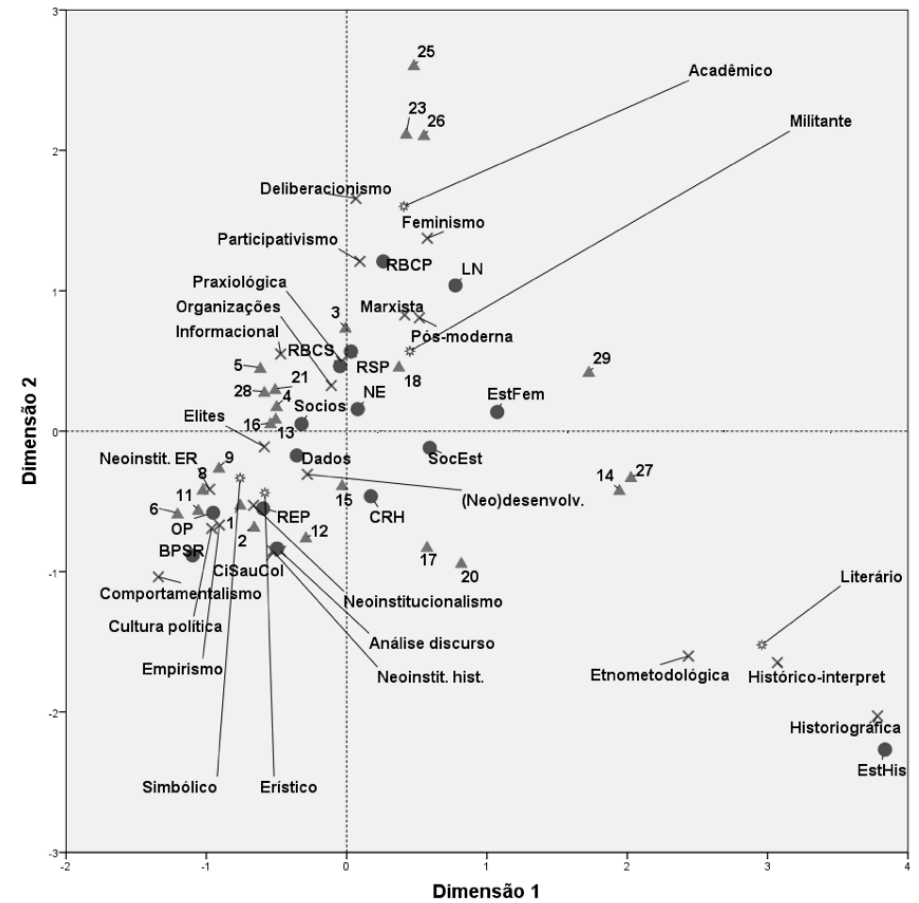

Nota: Dimensão 1: Alfa de Cronbach: .830; Variância contabilizada: 2 651; Inércia: .663. Dimensão 2: Alfa: .804; Variância: 2 519; Inércia: .630. Normalização simétrica.

"erístico" e "simbólico"; o humanístico, pelos "literário", "acadêmi$\mathrm{CO}^{\prime}$ e "militante". O modelo considerou periódicos, áreas e abordagens mais frequentes (dez, cinco e cinco casos, respectivamente).

O modelo humanístico cobre os estilos cognitivos posicionados no quadrante positivo (direita), opondo-se ao científico, no negativo (esquerda). Tem-se um contínuo científico-humanístico estruturando o campo na dimensão que mais contribui para a inércia total do modelo, ou seja, a mais importante na determinação de sua estrutura.

Essa grande oposição envolve oposições mais específicas. Tem-se um subgrupo destacado, o polo literário, opondo-se à nuvem central. Esse polo compõe-se, sobretudo, por abordagens históricas, além da etnometodológica. A proximidade entre História e estilo literário é frequentemente notada, mesmo entre autores que falam em uma "ciência histórica" (LeGoff, 2003). Essa associação se reproduz na Ciência Polí- 
tica brasileira e foi aqui insulada do mainstream. A Ciência Política brasileira parece reproduzir a tendência, observada na estadunidense, de distanciamento da História e do estilo literário (Jensen, 1969). Nesse sentido, ressalte-se que, na primeira dimensão, o polo literário opõese sobretudo ao grupo científico (erístico-simbólico).

Repare-se como não há áreas discriminadas no polo literário. Ou seja, não há suporte institucional a esse estilo na Ciência Política durante o período analisado. Os estudos mais literários concentram-se no periódico interdisciplinar Estudos Históricos. Repare-se também que há um claro contraste com outra abordagem histórica, o neoinstitucionalismo histórico, que estuda mais a política institucional. O estilo literário costuma lidar com objetos externos à política institucional, de natureza societal.

Também na primeira dimensão, com menos intensidade, o polo científico opõe-se aos estilos acadêmico e militante, ou seja, às regiões mais filosóficas da produção.

Na segunda dimensão as categorias se dispõem em função do contínuo empírico-teórico. O modelo científico se opõe ao estilo militante e, sobretudo, acadêmico, associados a áreas, abordagens e periódicos mais dedicados à teoria política normativa. $\mathrm{O}$ estilo literário também

\section{Gráfico 5}

Medidas de Discriminação para Estilos Cognitivos, Periódicos, Abordagens e Áreas

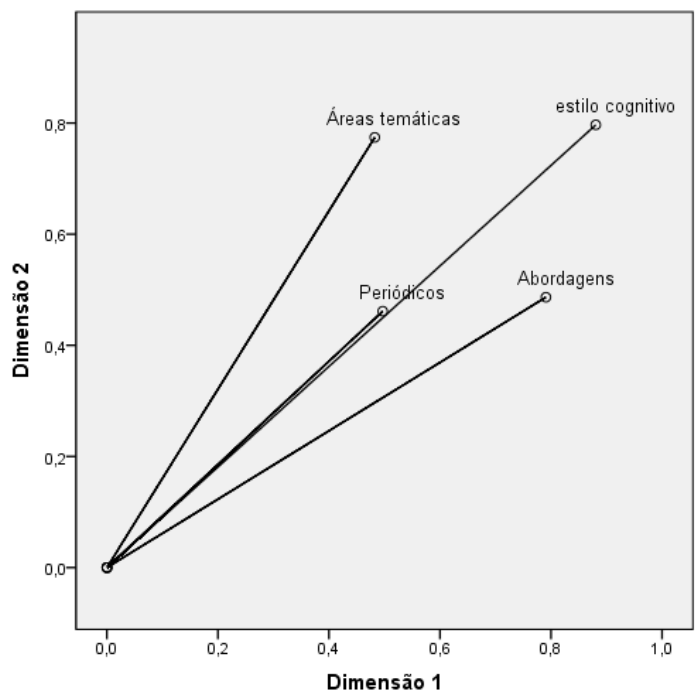

Fonte: $\mathrm{O}$ autor. 
aborda objetos empíricos, aproximando-se do polo científico na segunda dimensão.

As medidas de discriminação são demonstradas no Gráfico 5.

Todas as variáveis contribuem ativamente a ambas as dimensões. As áreas temáticas contribuem mais à segunda, na qual se ressalta a oposição entre as áreas de teoria política (associadas à tradição acadêmica) e as demais.

Periódicos são a variável que menos contribui para a discriminação das categorias. Ou seja, eles não são tão diferenciados como as categorias das demais variáveis. Os periódicos da Ciência Política brasileira não correspondem ao grau de diferenciação de áreas, abordagens e estilos cognitivos. Nesse sentido, repare-se que há uma grande defasagem entre as Áreas Temáticas da ABCP e a orientação temática dos periódicos, que, em geral, têm títulos genéricos. Isso pode apontar a uma maior especialização dos periódicos.

\section{AMPLITUDE E ESCOPO}

Verificamos que as tradições nomotética e idiográfica, objetivista e subjetivista também determinam a estrutura da produção, como mostrado no Gráfico 6.

Escopo e amplitude atuam de forma simétrica no campo. Na primeira dimensão, o campo se estrutura em função da proximidade com agência (+) e estrutura (-) e, na segunda, em função de nomotético (+) e idiográfico (-). Tem-se, portanto, correspondência (a) com idiográfico e agência no quadrante inferior direito; (b) idiográfico e estrutural no inferior esquerdo; (c) nomotético e estrutural no superior esquerdo; e (d) nomotético e agência no superior direito.

Quanto à amplitude, a oposição entre subjetivismo e objetivismo é mais clara nas abordagens historicamente mais importantes, como comportamentalismo, cultura política, pluralismo, escolha racional, os neoinstitucionalismos e a abordagem sistêmica. As quatro primeiras têm orientação mais subjetivista e as duas últimas mais objetivista.

Uma interpretação para a maior oposição subjetivista é a proeminência atual dos neoinstitucionalismos e o claro contraste de suas premissas em relação à cultura política, o que se manifesta no âmbito dos objetos (neoinstitucionalismos focando o núcleo da política institucional, cultura política e o ambiente societal a ela vinculado) e nos fatores mobiliza- 


\section{Gráfico 6}

Correspondência Múltipla para Periódicos, Abordagens, Áreas Temáticas,

Amplitude do Argumento e Escopo do Argumento ${ }^{15}$

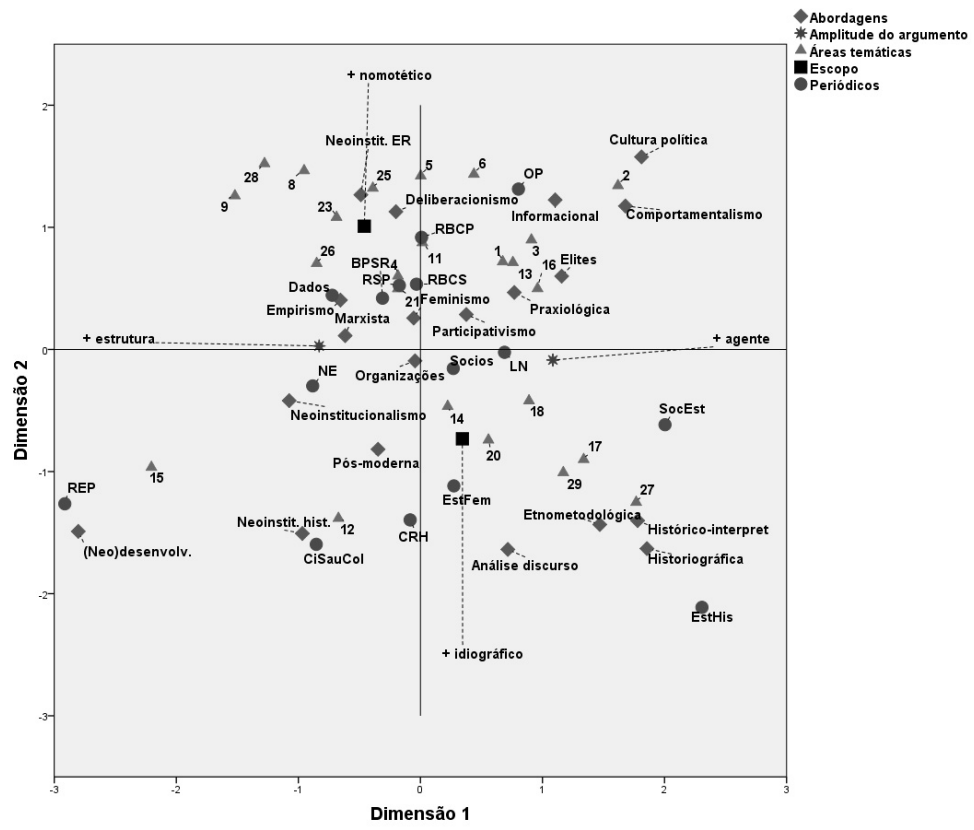

Fonte: $\mathrm{O}$ autor.

dos no argumento (cultura política considerando fatores societais, culturais, negados pelo neoinstitucionalismo político e, sobretudo, de escolha racional). Repare-se como as abordagens mais sociológicas geralmente também se baseiam em argumentos culturalistas, isto é, em padrões comportamentais definidos por normas incorporadas. Tem-se, portanto, uma oposição entre argumentos culturalistas, baseados em instituições definidas pela tradição sociológica, e argumentos político-institucionais, definidos pela tradição politológica.

Quanto ao escopo, cumpre destacar que embora uma concepção mais ortodoxa de ciência favoreça a orientação nomotética, os estudos mais idiográficos na Ciência Política brasileira não raramente apresentam hipótese (33,4\%), as quais 60,6\% são testadas, envolvem argumentos causais $(43,4 \%)$ e estatística $(36,2 \%)$. Uma adesão mais deliberada e sistemática ao que se entende por "método idiográfico" emerge nos periódicos mais literários, como Estudos Históricos, História e Estudos Feministas. Nesse sentido, um bom exemplo é a área "governo, buro- 
cracia e políticas públicas". A análise de resíduos padronizados indica fortes desvios de 3,4 para idiográfico (forte atração) e -4,1 para nomotético (forte repulsão), tratando-se da maior polarização da produção. Ao mesmo tempo, embora se associe com idiográfico, é uma área das mais erísticas. Estudos idiográficos mais literários associam-se com abordagens e áreas societais.

Note-se também como as áreas de teoria política $(23,25$ e 26) orbitam de perto o ponto nomotético: ecoando a tradição da "filosofia política" baseada nos clássicos, dirige-se à generalização teórica, muito diferente do relativismo dominante na Sociologia ou na Antropologia. Na Ciência Política brasileira, estudos com objetos empíricos podem ser nomotéticos ou idiográficos, mas objetos teóricos tendem a ser nomotéticos. Além disso, boa parte dos estudos idiográficos politológicos tendem a organizar-se de forma cumulativa, agregando evidências de casos concretos para fazer generalizações empíricas ${ }^{16}$. O núcleo da Ciência Política brasileira deseja colocar o caso particular a serviço da generalização.

O Gráfico 7, a seguir, apresenta as medidas de discriminação, indicando que escopo e amplitude determinam a estrutura em grau razoável.

\section{Gráfico 7}

Medidas de Discriminação para Periódicos, Abordagens, Áreas Temáticas, Amplitude do Argumento e Escopo do Argumento

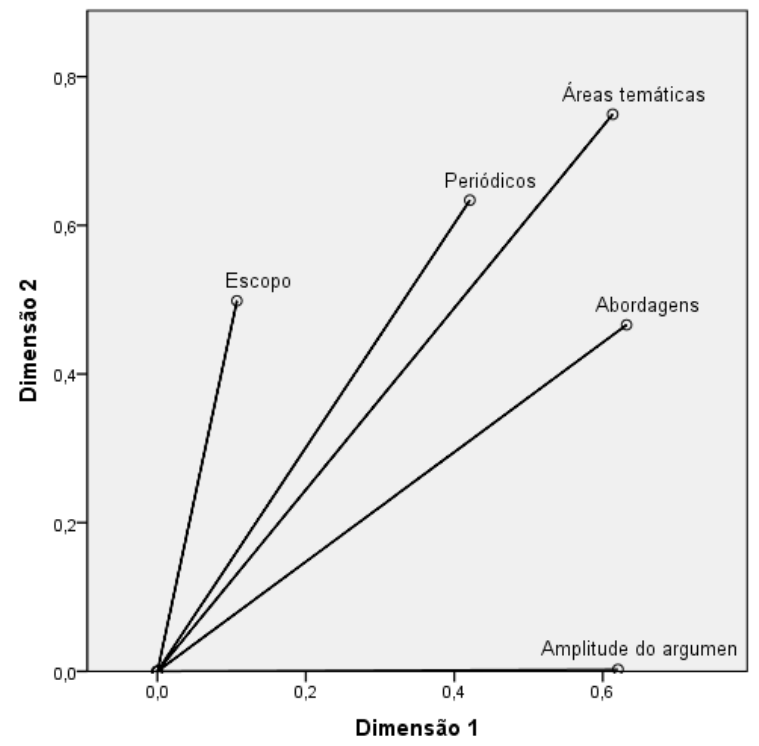

Fonte: $\mathrm{O}$ autor. 


\section{CONCLUSÕES}

O estudo verificou que oposições tradicionais do campo intelectual e das Ciências Sociais se aplicam à Ciência Política brasileira atual. Em primeiro lugar, a Ciência Política está dividida entre áreas e abordagens teóricas e empíricas. Esses resultados diferem da opinião de Amorim Neto e Santos (2015), para quem a falsa dicotomia entre uma Ciência Política empírica e teórica foi superada. Os dados mostram que persiste uma oposição entre estudos empíricos e teóricos. O que ocorreu é que a Ciência Política se estabeleceu como uma disciplina empirica, de modo que os estudos teóricos foram insulados do mainstream. Isso não quer dizer que os estudos empíricos não sejam teoricamente informados ou não tenham pretensões nomotéticas. A oposição parte de áreas de teoria pura.

Esses resultados concordam com a estrutura da Ciência Política estadunidense, na qual political philosophy é destacada do mainstream ao ponto de quase constituir uma disciplina autônoma (Grant, 2005). Outras análises reproduzem esses resultados, referindo-se especificamente à oposição entre abordagens empíricas e teóricas e modelos de atividade intelectual (Lipset, 1969; Bellamy, 1993; Almond, 1990; 1991; Riba, 1996).

Acreditamos que a Ciência Política brasileira tenha se autonomizado, em boa medida, importando o modelo estadunidense. Para justificar a autonomia disciplinar, precisou demonstrar e defender a autonomia de um objeto específico, a política institucional. Mas, além disso, a autonomização também passou pela defesa de uma epistemologia e um modelo de atividade intelectual específico, calcados no empirismo epistêmico e no modelo do acadêmico especialista, no final da década de 1960, com o grupo de cientistas políticos mineiros e cariocas responsáveis pela fundação da pós-graduação de Ciência Política no Brasil. Seu principal adversário foi o marxismo teórico - ao mesmo tempo societal e, a seu ver, anticientífico. A partir da década de 1990, assistimos ao crescimento das abordagens institucionalistas, em detrimento, sobretudo, do marxismo. Hoje, todas as abordagens mais importantes são empiricamente orientadas e podem ser consideradas "positivistas". O crescimento e o prestígio dos métodos quantitativos e de propriedades típicas de um modelo mais ortodoxo de ciência (Leite, 2016), como apresentação e teste de hipóteses, argumentos causais e orienta- 
ção nomotética reforçam o diagnóstico. O crescimento e a valorização de estudos metodológicos, em oposição aos "epistemológicos" é outro importante elemento desse processo, também à imagem da Ciência Política estadunidense.

A principal diferença em relação aos Estados Unidos é que, aqui, foi necessário opor-se e destacar-se tanto da tradição societal como da tradição humanística. Nos Estados Unidos a questão maior foi a afirmação como ciência, dado que a Ciência Política já nasce próxima à política institucional, devido ao seu propósito de melhorar a democracia estadunidense. Ela, inclusive, sacrificaria parcialmente sua autonomia intelectual, adotando abordagens externas, como da Psicologia, na primeira fase do behavioralism (1920-1940), em prol de ganhos de cientificidade - objetos empíricos, métodos quantitativos e propósito nomotético, sobretudo.

A oposição entre estilos cognitivos e, possivelmente, entre escopos (nomotético e idiográfico) inserem-se nesse processo. Conflitos que perpassaram o campo intelectual por séculos, como entre a filosofia escolástica, as humanidades e as ciências naturais, entre os séculos XVI e XIX, sintetizam-se aqui em um espaço tão curto quanto 50 anos, e persistem até hoje. Em situações aparentemente tão banais do ponto de vista da história do conhecimento, como os atuais debates sobre o Sistema Qualis, temos um estranhamento entre modelos distintos de atividade intelectual: ciências empíricas, filosofia e literatura.

Por fim, há uma importante dimensão que aqui não exploramos. A autonomização de uma disciplina, e sua estrutura, estão ligados, e mesmo dependem, de uma hierarquia. Um campo não comporta apenas diferenças. A pluralidade é perpassada por desigualdades - de recursos destinados aos programas de pós-graduação, de prestígio, de influência sobre a produção. A distribuição desigual de valor influencia o futuro da disciplina ao estimular a adesão às categorias mais valorizadas e inflamar a oposição a elas, pelos desviantes. Estudar essa dimensão do campo é fundamental porque boa parte dos diagnósticos sobre a disciplina são também posicionamentos no campo, a partir do estado de coisas desejado: a avaliação do que a disciplina é depende do que ela deve ser. Essa confusão é mais clara nos artigos de opinião. Nos estudos empíricos, contaminam as categorias usadas para descrever a produção, reduzindo a disciplina a uma visão disciplinar especí- 
fica. Um esforço para identificar a estrutura de oposições em conjunto com sua hierarquia é imprescindível para um melhor esclarecimento do estado e do futuro da disciplina.

(Recebido para publicação 11 de novembro de 2015) (Reapresentado em agosto de 2016) (Aprovado 7 de dezembro de 2016) 


\section{NOTAS}

1. A Coordenação de Aperfeiçoamento de Pessoal de Nível Superior (CAPES) é a agência federal responsável por fixar as regras de avaliação dos programas de pós-graduação. Parte importante da avaliação refere-se à quantidade e à qualidade das publicações. A qualidade das publicações é medida a partir de um sistema de avaliação de periódicos, denominado Sistema Qualis, no qual cada área de conhecimento distribui os periódicos nacionais e estrangeiros nos seguintes estratos: A1, A2, B1 a B5 e C. Já faz algum tempo que a produção qualificada na área de Ciência Política é definida como aquela publicada exclusivamente em periódicos A1, A2 e B1.

2. Neiva (2015) retoma as hipóteses de Soares (2005) e as testa com mais rigor metodológico, verificando o crescimento do emprego de métodos quantitativos nas Ciências Sociais. Seu objetivo não é identificar os fatores que estruturam a produção.

3. Outros fatores importantes referem-se a tradições disciplinares, como visões que privilegiam o estudo da política institucional e que privilegiam fenômenos societais, em concepções mais amplas de poder. Essa dimensão será abordada em outro trabalho.

4. São eles: DADOS (54,2\%), Revista Brasileira de Ciências Sociais (34,1\%), Opinião Pública (100\%), Brazilian Political Science Review (86,6\%), Revista de Sociologia e Politica (69,3\%), Lua Nova (59,1\%), Revista de Economia Política (7,8\%), Novos Estudos (32\%), Revista Brasileira de Ciência Política (91,3\%), Caderno CRH (21,7\%), Ciência e Saúde Coletiva $(6,6 \%)$, Estudos Históricos (24,5\%), História (6,8\%), Religião e Sociedade (16\%), Revista Estudos Feministas (12,6\%), Saúde e Sociedade (1,1\%), Sociedade e Estado (17,7\%), Sociologias (16,6\%), Tempo Social (1,5\%) e Ambiente e Sociedade (10,6\%).

5. Tendo em vista os critérios de seleção, as inferências envolvendo periódicos restringem-se à produção de Ciência Política nesses periódicos, não podendo ser generalizadas para os periódicos como um todo. A exceção é Opinião Pública, em que todos os artigos foram analisados.

6. “Tabela de Áreas de Conhecimento", Capes, 2012. Disponível em <http:/ / www.capes.gov.br/avaliacao/instrumentos-de-apoio/tabela-de-areas-do-conhecimento-avaliacao>. Acesso em 30 maio 2014.

7. “Áreas temáticas", ABCP, 2012. Disponível em <http://www.cienciapolitica.org.br/encontros/8o-encontro-abcp/areas-tematicas/>. Acesso em 30 maio 2013.

8. A listagem completa pode ser consultada em Leite (2015:161).

9. Para mais detalhes, cf. Leite (2015:155-160).

10. Atente-se que "estrutura" não se confunde com a abordagem estruturalista: pode-se mobilizar fatores estruturais em estudos que focam atores ou a ação de grupos. Um trabalho cuja amplitude é mais estrutural não é necessariamente um estudo estruturalista.

11. Valores iguais ou superiores a 2,0 indicam que a concentração de ocorrências não se dá ao acaso. Ou seja, os resíduos apontam em quais categorias, especificamente, encontram-se as associações.

12. Para mais detalhes, cf. Leite (2015:157). 
13. Os seguintes parâmetros foram adotados: periódicos com pelo menos dez casos e abordagens e áreas com pelo menos cinco. A abordagem historiográfica, um outlier, foi excluída. O neodesenvolvimentismo constitui um polo à parte da estrutura principal, junto da Revista de Economia Política, também excluídos. Linguístico-ideal forma um microcosmo com as abordagens história conceitual, contextualismo linguístico (excluídas pelo critério de frequência), a área "história das ideias" e Estudos Históricos, também destacado da estrutura principal. A natureza do objeto foi restrita a empírico e teórico.

14. Parâmetros do modelo: Dimensão 1: Alfa de Cronbach: .830; Variância contabilizada: 2 651; Inércia: .663. Dimensão 2: Alfa: .804; Variância: 2 519; Inércia: .630. Normalização simétrica.

15. Parâmetros do modelo: Dimensão 1: Alfa de Cronbach: .728; Variância contabilizada: 2394; Inércia: .479. Dimensão 2: Alfa: .718; Variância: 2 350; Inércia: .470. Normalização simétrica.

16. O próprio foco do neoinstitucionalismo sobre instituições formais é um exercício de empirismo básico, envolvendo também uma relação muito próxima entre neoinstitucionalismo, democracia, formalismo e empirismo. Isso será desenvolvido nas conclusões. 


\section{REFERÊNCIAS BIBLIOGRÁFICAS}

ALMEIDA, Maria Hermínia T. (2001), "Dilemas da Institucionalização das Ciências Sociais no Rio de Janeiro", in S. Miceli (ed.), História das Ciências Sociais no Brasil, vol. 1. São Paulo, Sumaré.

ALMOND, Gabriel. (1990), A Discipline Divided. Newbury Park: Sage Publications.

. (1991), "Political Science: The History of the Discipline", in R. E. Goodin; H-D. Klingemann (eds.), A New Handbook of Political Science. New York, Oxford University Press, pp. 50-96.

AMORIM NETO, Octavio; SANTOS, Fabiano. (2015), “La Ciencia Política en Brasil en la Última Década: La Nacionalización y la Lenta Superación del Parroqualismo". Revista de Ciencia Política, vol. 35, no 1, pp. 19-31.

ARRUDA, Maria Arminda do Nascimento. (1995), "A Sociologia no Brasil: Florestan Fernandes e a 'Escola Paulista'", in S. Miceli (ed.), História das Ciências Sociais no Brasil, vol. 2. São Paulo, Sumaré.

. (2001), "A Modernidade Possível: Cientistas e Ciências Sociais em Minas Gerais", in S. Miceli (ed.), História das Ciências Sociais no Brasil, vol. 1, São Paulo, Sumaré.

BELLAMY, Richard. (1993), "Introduction: The Demise and Rise of Political Theory", in R. Bellamy (ed.), Theories and Concepts of Politics. An Introduction. Manchester/New York, Manchester University Press.

BOURDIEU, Pierre. (1984), Distinction. A Social Critique of the Judgment of Taste. Cambridge, MA, Harvard University Press.

. (1996), As Regras da Arte. Gênese e Estrutura do Campo Literário. São Paulo, Companhia das Letras.

BURKE, Peter. (2000), A Social History of Knowledge: From Gutenberg to Diderot. Cambridge, UK, Polity Press.

CANO, Ignacio. (2012), “Nas Trincheiras do Método: O Ensino da Metodologia das Ciências Sociais no Brasil”. Sociologias, vol. 14, no 31, pp. 94-119.

ELIAS, Norbert. (2000), Os Estabelecidos e os Outsiders. Rio de Janeiro, Jorge Zahar Editor.

FORJAZ, Maria Cecília Spina. (1997), “A Emergência da Ciência Política no Brasil: Aspectos Institucionais". Revista Brasileira de Ciências Sociais, vol. 12, no 35.

GARDNER, Thomas. (2014), Poverty Creek Journal. North Adams, Tupelo Press.

GRANT, J. Tobin. (2005), “What Divides Us? The Image and Organization of Political Science". Political Science and Politics, vol. 38, no 3, pp. 379-386.

GREENACRE, Michael. (1984), Theory and Applications of Correspondence Analysis. London, Academic Press.

JENSEN, Richard. (1969), "History and the Political Science", in S. Lipset (ed.), Politics and the Social Sciences. New York, Oxford University.

KAPLAN, Abraham. (1964), The Conduct of Inquiry. Methodology for Behavioral Science. San Francisco, Chandler. 
KEINERT, Fábio Cardoso; SILVA, Dimitri Pinheiro. (2010), "A Gênese da Ciência Política Brasileira". Tempo Social, vol. 22, no 1, pp. 79-98.

KUHN, Thomas S. (1962), The Structure of Scientific Revolutions. 2a ed. Chicago, University of Chicago Press.

LAMOUNIER, Bolivar. (1982), “A Ciência Política no Brasil: Roteiro para um Balanço Crítico", in B. Lamounier (ed.), A Ciência Política nos Anos 80. Brasília, UnB.

LEGOFF, Jacques. (2003), História e memória. $5^{\text {a }}$ ed. Campinas, Unicamp.

LEITE, Fernando. (2015), O Campo de Produção da Ciência Política Brasileira Contemporânea: Uma Análise Histórico-estrutural de seus Princípios de Divisão a partir de Periódicos, Áreas e Abordagens. Tese (Doutorado em Sociologia). Programa de Pós-Graduação em Sociologia, Universidade Federal do Paraná, Curitiba.

. (2016), The Stratification of Diversity: Measuring the Hierarchy of Brazilian Political Science. Brazilian Political Science Review, vol. 10, no 1, pp. 1-29.

; CODATO, Adriano. (2013), "Autonomização e Institucionalização da Ciência Política Brasileira: O Papel do Sistema Qualis-Capes". Revista de Discentes de Ciência Política da UFSCAR, vol. 1, no 1, pp. 1-21.

LEPENIES, Wolf. (1996), As Três Culturas. São Paulo, Edusp.

LESSA, Renato. (2010), “O Campo da Ciência Política no Brasil: Uma Aproximação Construtivista", in C. B. Martins; R. Lessa (eds.), Horizontes das Ciências Sociais no Brasil. Ciência Política. São Paulo, Anpocs.

. (2011), “Da Interpretação à Ciência: Por uma História Filosófica do Conhecimento Político no Brasil". Lua Nova, no 82, pp. 17-60.

LIMA JÚNIOR, Olavo Brasil. (1999), "Partidos, Eleições e Poder Legislativo”, in S. Miceli (org.), O Que Ler na Ciência Social Brasileira. 1970-1995. São Paulo, Sumaré, vol. 3.

LIPSET, Seymour Martin. (1969), “Politics and the Social Sciences: Introduction”, in S. M. Lipset (ed.), Politics and the Social Sciences. New York, Oxford University.

MARENCO, André. (2015), “The Three Achilles' Heels of Brazilian Political Science”. Brazilian Political Science Review, vol. 8, no 3, pp. 3-38.

MARTINS, Luciano. (1987), "A Gênese de uma Intelligentsia. Os Intelectuais e a Política no Brasil: 1920 a 1940". Revista Brasileira de Ciências Sociais, vol. 2, no 4, pp. 65-87.

MICELI, Sergio. (1990), A Desilusão Americana. Relações Acadêmicas entre Brasil e Estados Unidos. São Paulo, Sumaré.

. (1993), A Fundação Ford no Brasil. São Paulo, Sumaré.

NEIVA, Pedro. (2015), "Revisitando o Calcanhar de Aquiles Metodológico das Ciências Sociais no Brasil". Sociologia, Problemas e Práticas, no 79, pp. 65-83.

PEIXOTO, Fernanda. (2001), “Franceses e Norte-Americanos nas Ciências Sociais Brasileiras (1930-1960)", in S. Miceli (org.), História das Ciências Sociais no Brasil, vol. 1. São Paulo, Sumaré.

POGREBINSCHI, Thamy. (2014), "Democracia Pragmática: Pressupostos de uma Teoria Normativa Empiricamente Orientada". DADOS - Revista de Ciências Sociais, vol. 53, no 3, pp. 657-693. 


\section{Fernando Leite}

QUIRINO, Célia. (1994), “Departamento de Ciência Política”. Estudos Avançados, vol. 8, no 32, pp. 337-348.

REIS, Fabio Wanderley. (1997), "As Ciências Sociais nos Últimos 20 Anos". Revista Brasileira de Ciências Sociais, vol. 12, no 35.

RIBA, Clara. (1996), "The Use of Mathematics in Political Science". European Journal of Political Research, no 29, pp. 477-508.

SAID, Edward W. (2005), Representações do Intelectual: As Conferências Reiht de 1993. São Paulo, Companhia das Letras.

SAMSON, Ashley et al. (2015), "Think Aloud: An Examination of Distance Runners' Thought Processes". International Journal of Sport and Exercise Psychology, vol. 15, número especial, pp. 1-14.

SNOW, Charles P. (1959), The Two Cultures and the Scientific Revolution. New York, Cambridge University Press.

SOARES, Gláucio Ary Dillon. (2005), “O Calcanhar Metodológico da Ciência Política no Brasil”. Sociologias, Problemas e Práticas, no 48, pp. 27-52.

TRINDADE, Helgio. (2007), “Ciências Sociais no Brasil em Perspectiva: Fundação, Consolidação e Expansão”, in H. Trindade (org.), As Ciências Sociais na América Latina em Perspectiva Comparada. 2a ed. Porto Alegre, Editora da UFRGS.

. (2012), Ciências Sociais no Brasil. Diálogos com Mestres e Discípulos. São Paulo, Anpocs.

WAIZBORT, Leopoldo. (2006), As Aventuras de Georg Simmel. São Paulo, Editora 34.

WERNECK VIANNA, Luiz et al. (1998), “Doutores e Teses em Ciências Sociais”. DADOS

- Revista de Ciências Sociais, vol. 41, no 3, pp. 453-516. 


\section{APÊNDICE}

\section{Áreas temáticas}

1. Estudos eleitorais e partidos políticos; 2. Atitudes e cultura política; 3. Comunicação política e opinião pública; 4 . Instituições participativas; 5 . Estudos do Legislativo; 6. Relações Executivo-Legislativo; 7. Relações intergovernamentais; 8 . Sistemas eleitorais e sistemas partidários; 9. Sistemas governamentais; 10. Instituições governamentais específicas; 11. Análise do processo decisório; 12. Governo, burocracia e políticas públicas; 13. Estudos do poder local; 14. Estrutura e transformação do Estado; 15. Política e economia; 16. Recrutamento político, jurídico e burocrático; 17. Classes sociais e grupos de interesse; 18. Movimentos, organizações e atores coletivos; 19. Revoluções e conflitos civis; 20. Segurança pública; 21. Política, direito e judiciário; 22. Religião e política [omitido]; 23. Teoria política democrática; 24. Teoria política clássica; 25. Teoria política moderna; 26. Teoria política contemporânea; 27. História das ideias; 28. Metodologia; 29. Pensamento político brasileiro. 
RESUMO

Tradições Intelectuais na Ciência Política Brasileira Contemporânea

O artigo analisa o papel de diversas tradições intelectuais na estruturação da produção da Ciência Política brasileira. Toma-se como referência a produção veiculada nos 23 periódicos nacionais A1, A2 e B1 listados no Qualis da área de Ciência Política, relativa ao triênio de 2010-2012. A partir de categorias como periódicos, áreas temáticas e abordagens, usa-se técnicas de redução dimensional e verifica-se que certas tradições intelectuais - "humanística" e "científica", nomotética e ideográfica - contribuem para determinar essa estrutura. Oposições específicas, como entre tradições "teórica" e "empírica", também contribuem para estruturar a oposição. Argumenta-se que a Ciência Política brasileira autonomiza-se privilegiando uma tradição científica mais ortodoxa.

Palavras-chave: Ciência Política Brasileira; revistas científicas; produção acadêmica; tradições intelectuais; autonomização

\section{ABSTRACT \\ Intellectual Traditions in Contemporary Brazilian Political Science}

The following article analyzes the role played by various intellectual traditions in the structuring of the output of Brazilian political science, referring to 23 national A1, A2 and B1 journals listed in the field of political science by the Qualis classification system and published in the 2010-2012 triennium. Based on categories such as journals, thematic areas and approaches, dimensional reduction techniques are used, demonstrating that certain intellectual traditions, whether "humanistic", "scientific", nomothetic or ideographic, contribute to the determining of this structure. Specific oppositions, such as those between "theoretical" and "empirical" traditions, also contribute to the structuring of this opposition. The article argues that Brazilian political science is developing its own identity, favoring a more orthodox scientific tradition.

Keywords: Brazilian Political Science; scientific journals; academic output; intellectual traditions; independence 


\section{RÉSUMÉ}

Traditions Intellectuelles en CEuvre dans les Sciences Politiques

\section{Brésiliennes Contemporaines}

Cet article analyse le rôle de diverses traditions intellectuelles dans la structuration de la production des sciences politiques brésiliennes. On prendra comme référence la production véhiculée par les 23 périodiques nationaux de sciences politiques $\mathrm{A} 1, \mathrm{~A} 2$ et $\mathrm{B} 1$ répertoriés dans la banque de données Qualis entre 2010 et 2012. À partir de catégories telles que périodiques, domaines thématiques et approches, on a utilisé des méthodes de réduction dimensionnelle pour constater que certaines traditions intellectuelles - "humanistique" et "scientifique", nomothétique et idéographique - ont contribué à déterminer cette structure. Des oppositions spécifiques, comme entre traditions "théorique" et "empirique", ont également contribué à structurer cette opposition. Nous soutenons ici que les sciences politiques brésiliennes ont néanmoins développé une identité propre en privilégiant une tradition scientifique plus orthodoxe.

Mots-clés: sciences politiques brésiliennes; politique brésiliennes; revues scientifiques; production académique; traditions intellectuelles; autonomisation

\section{RESUMEN}

Tradiciones Intelectuales en la Ciencia Política Brasileña Contemporánea

El artículo analiza el rol de diversas tradiciones intelectuales en la estructuración de la producción de la ciencia política brasileña. Se toma como referencia la producción publicada en los 23 periódicos nacionales A1, A2 y B1 enumerados en el Qualis del área de la ciencia política, referente al trienio de 2010 a 2012. A partir de categorías como periódicos, áreas temáticas y enfoques se utilizan técnicas de reducción dimensional y se verifica que determinadas tradiciones intelectuales - "humanística" y "científica", nomotética e ideográfica contribuyen a determinar esa estructura. Oposiciones específicas, como entre las tradiciones "teórica" y "empírica", también contribuyen a estructurar la oposición. Se plantea que la ciencia política brasileña se hace autónoma privilegiando una tradición científica más ortodoxa.

Palabras clave: Ciencia Política Brasileña; revistas científicas; producción académica; tradiciones intelectuales; autonomía 